\title{
Effect of Cyclic Fatigue Tests on Aging and Their Translational Implications for Survival of All-Ceramic Tooth-Borne Single Crowns and Fixed Dental Prostheses
}

\author{
Özcan, Mutlu ; Jonasch, Moritz
}

\begin{abstract}
PURPOSE The objective of this systematic review was to elaborate the aging effect of cyclic fatigue tests on mechanical durability of all-ceramic single crowns and fixed dental prostheses (FDP). MATERIALS AND METHODS Original scientific papers published in the MEDLINE (PubMed) database in English between 01/01/1950 and 12/31/2013 on cyclic loading on all-ceramics were included in this systematic review. The following MeSH terms, search terms, and their combinations were used: "in vitro," "stress mechanical," "crowns," "denture, partial, fixed," "dentistry," "fatigue," "all-ceramic," "zirconia," "fixed dental prosthesis," "FDP," "bridges," and "cyclic loading." Two reviewers performed screening and analyzed the data. Only the studies that reported on both static fracture strength and static fracture after fatigue of all-ceramic single crowns and FDPs that allowed comparison of aging effect through cyclic loading were included. RESULTS The selection process resulted in a final sample of 14 journal articles. In total, 9 articles were identified related to all-ceramic single crowns, 3 of which were on anterior and 6 on posterior crowns, and 5 articles on 3 -unit FDPs, all of which were on posterior FDPs. Fatigue cycles varied between minimum of 1000 to maximum 1,200,000 cycles for crowns and 10,000 to 2,000,000 cycles for 3-unit FDPs. The applied force during cyclic loading varied between 20 to $300 \mathrm{~N}$ for single crowns and 49 to $200 \mathrm{~N}$ for 3-unit FDPs. For the 3-unit FDPs, fracture strength results showed slightly decreased values after cyclic loading $(659 \pm 182$ to $2333 \pm 183 \mathrm{~N})$ compared to static loading only (841 \pm 244 to $2434 \pm 154 \mathrm{~N}$ ). For crowns similar trends were not observed, but cyclic loading decreased the fracture strength in only some materials after cyclic loading $(659 \pm 182$ to $2333 \pm 183 \mathrm{~N})$ compared to static loading only $(395 \pm 96$ to $2726 \mathrm{~N})$. CONCLUSIONS An inclination for decreased static fracture strength could be observed after cyclic loading of all-ceramic single crowns and FDPs, but this was material specific. Due to the heterogeneity of data such as aging, loading conditions, and fewer experimental groups, statistical analysis could not be performed. Cyclic loading tests require more standardized guidelines for testing and reporting.
\end{abstract}

DOI: https://doi.org/10.1111/jopr.12566

Posted at the Zurich Open Repository and Archive, University of Zurich

ZORA URL: https://doi.org/10.5167/uzh-162680

Journal Article

Accepted Version

Originally published at:

Özcan, Mutlu; Jonasch, Moritz (2018). Effect of Cyclic Fatigue Tests on Aging and Their Translational Implications for Survival of All-Ceramic Tooth-Borne Single Crowns and Fixed Dental Prostheses. Journal of Prosthodontics, 27(4):364-375. 
DOI: https://doi.org/10.1111/jopr.12566 
Effect of cyclic fatigue tests on aging and their translational implications for survival of all-ceramic tooth-borne single crowns and fixed dental prosthesis

\section{Mutlu Özcan a, ${ }^{\mathrm{*}}$, Moritz Jonasch ${ }^{\mathrm{a}}$}

aUniversity of Zürich, Dental Materials Unit, Center for Dental and Oral Medicine, Clinic for Fixed and Removable Prosthodontics and Dental Materials Science, Plattenstrasse 11, CH-8032, Zurich, Switzerland

Short title: Cyclic fatigue of all-ceramic restorations

*Corresponding author at: Mutlu Özcan, Prof. Dr.med.dent., Ph.D., Dental Materials Unit, University of Zurich, Center for Dental and Oral Medicine, Clinic for Fixed and Removable Prosthodontics and Dental Materials Science, Plattenstrasse 11, CH 8032, Zurich, Switzerland. Tel: +4144 6343251; fax: +41446344305.

E-mail address: mutluozcan@hotmail.com 


\section{ABSTRACT}

Purpose: The objective of this systematic review was to elaborate the aging effect of cyclic fatigue tests on mechanical durability of all-ceramic single crowns and fixed-dental prosthesis (FDP).

Materials and Methods: Original scientific papers published in MEDLINE (PubMed) database in English between $01 / 01 / 1950$ and $12 / 31 / 2013$ on cyclic loading on all-ceramics were included in this systematic review. The following MeSH terms, search terms and their combinations were used: "in vitro", "stress mechanical", "crowns", "denture, partial, fixed", "dentistry", "fatigue", "all-ceramic", "zirconia", "fixed dental prosthesis", "FDP", "bridges", "cyclic loading". Two reviewers performed screening and analyzed the data. Only the studies that reported on both static fracture strength and static fracture after fatigue of all-ceramic single crowns and FDPs were included that allowed comparison of aging effect through cyclic loading.

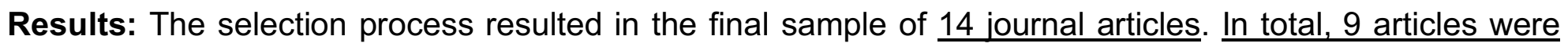
identified related to all-ceramic single crowns, 3 of which were on anterior and 6 on posterior crowns, and

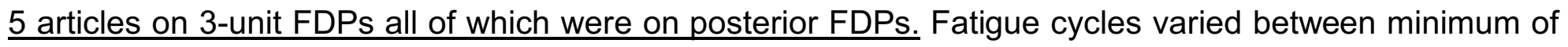
1000 to maximum 1.200 .000 cycles for crowns and 10.000 to 2.000 .000 cycles for 3 -unit FDPs. The applied force during cyclic loading varied between 20 to $300 \mathrm{~N}$ for the 3-unit FDPs and 49 to $200 \mathrm{~N}$ for single crowns. For the 3-unit FDPs, fracture strength results showed slightly decreased values after cyclic loading $(659 \pm 182-2333 \pm 183 \mathrm{~N})$ compared to static loading only $(841 \pm 244-2434 \pm 154 \mathrm{~N})$. For crowns similar trend could not be observed but cyclic loading decreased the fracture strength in only some materials after cyclic loading $(659 \pm 182-2333 \pm 183 N$ ) compared to static loading only $(395 \pm 96-2726 N$ ).

Conclusion: An inclination for decreased static fracture strength could be observed after cyclic loading of all-ceramic single crowns and FDPs but this was material specific. Due to heterogeneity of data such as aging, loading conditions, and less number of experimental groups, statistics could not be performed. Cyclic loading tests require more standardized guidelines for testing and reporting.

Keywords: Aging; All-ceramic; Cyclic loading; Cyclic fatigue; Dynamic loading; Fatigue loading; Fatigue test; FDP; FPD; Fracture strength; In vitro; Load-bearing capacity; Test method; Tooth-borne fixed dental prosthesis 


\section{Introduction}

Investigations on durability of restorations are crucial for clinical dentistry since mechanical failures in the form of fractures have financial consequences both for the patient and the dentist. Removal and repair of restorations may be arduous and have also biological costs. Since durability testing of dental restorations in clinical trials is not possible due to technical and ethical considerations, materials and techniques are often tested in vitro. The testing and evaluation of the material characteristics and durability prior to clinical use is essential to avoid both financial and biological costs.

Load to fracture test is a common way of testing dental materials used for fixed dental prosthesis (FDP) to assess their mechanical strength for different indications. Today, an increased plethora of metal, allceramic or polymeric materials are being offered for clinical use. Neither ethically, nor technically it is possible to test their performance in randomized controlled clinical trials. Therefore, preclinical evaluations help to rank physical and mechanical properties of materials. Ranking prosthetic materials after such tests are generally taken into consideration for clinical indications especially for posterior segments of the mouth where increased chewing forces are experienced. Static load-bearing tests require a controlled environment where the specimen dimensions and the loading conditions are standardized. Although there are norms for static testing FDP materials (DIN EN ISO 22674), ${ }^{23}$ among in vitro tests, a great heterogeneity is being noticed in the dental literature related to load to fracture tests. ${ }^{31}$ Moreover their clinical relevancy is being questioned since the magnitude of loading is not representative of restorations in service and does not incorporate factors related to environmental effects. ${ }^{31}$ On the other hand, in vitro studies involving fatigue tests may have more translational meaning as they simulate the in vivo environment. This type of preclinical examination helps to rank the growing possibilities of various materials and techniques for the dental restorations for certain clinical indications that demand different physical and mechanical properties. Fatigue testing requires a controlled and standardized environment prior to investigate the cause of failure due to evaluation of different clinical indication for varying dental materials such as metal-ceramics, all-ceramics where the latter is more prone to fractures clinically. 
The objective of this systematic review therefore was to elaborate the aging effect of cyclic fatigue tests on mechanical durability of all-ceramic single crowns and fixed-dental prosthesis (FDP).

\section{Material and methods}

\subsection{Search strategy}

An electronic search at MEDLINE (PubMed) (http://www.ncbi.nlm.nih.gov/pubmed/) from 01/01/1950 to 31/12/2013 was conducted for English articles. Following MeSH terms, search terms and their combinations were used for this search: "in vitro", "stress mechanical", "crowns", "denture, partial, fixed", "dentistry", "dental implants", "cyclic loading", "fatigue", "all-ceramic", "zirconia", "fixed dental prosthesis", "FDP", "bridges". The MEDLINE search yielded 709 journal articles to be screened for possible inclusion based on titles and abstracts. A further manual search covering the period from 01/01/1981 up to and including 31/12/2013 was performed on the following journals: Journal of Dental Research, Dental Materials, International Journal of Prosthodontics, Journal of Prosthetic Dentistry, Journal of Prosthodontics, and European Journal of Prosthetic and Restorative Dentistry. $\underline{\text { In addition, hand searches }}$ were performed on bibliographies of the selected articles as well as identified narrative reviews to find out whether the search process has missed any relevant article. This did not add to additional articles to be involved in the review process.

\subsection{Inclusion/Exclusion criteria}

Journal articles in English concerning in vitro studies of all-ceramic restorations reporting on fracture strength before and after cyclic fatigue tests were included. Articles were not included if results were not presented in Newtons $(\mathrm{N})$, specimens were not loaded vertically, studies included implants or posts or articles with in vitro tests of inlays or overlays. This review focused on bilayered ceramic materials, therefore monolithic restorations have been excluded. Also, cantilever FDPs and extension units were not involved in the revision. 


\subsection{Selection of studies}

The search process led to titles of 709 journal articles that were reviewed by two independent reviewers (M.J. and M.Ö.), for possible inclusion in this systematic review. After title screening, 237 abstracts were selected. From abstract evaluation, 109 were considered relevant and full text articles were downloaded. Thereafter, from 109 journal articles, 14 were them were included in this review. Process of identifying the studies included in the review is presented in Fig. 1.

\subsection{Data extraction}

The data collection form containing 40 items was created and used to evaluate the experimental environment of the in vitro studies described in the 14 relevant articles concerning cyclic fatigue tests. Disagreement regarding data extraction was resolved by discussion and a consensus was reached. The variables were recorded and tabulated in Excel sheets. The variables that could not be extracted or calculated were scored as 'not reported'.

\subsection{Statistical analysis}

Statistical analyses were performed using the Statistical Package for the Social Sciences (version 18.0, SPSS Inc, Chicago, IL, USA). Abstracts of the full articles were used for the inter-observer agreement expressed as weighted Cohen's kappa. For descriptive statistics means and standard deviations, or medians and interquartile ranges in skewed distributions were noted. At least 6 experimental groups with identical test parameters were needed to run statistical analysis. Due to heterogeneity of information or insufficient number of experimental groups, data could not be analyzed even using Stängel-BlattDiagramme.

\section{Results}

The Kappa score for agreement between the reviewers after screening the abstracts was 0.85 . The selection process resulted in the final sample of $\underline{14 \text { journal articles }} .{ }^{5,11,16,18,24,33,34,36,55-58,66,67} \underline{\ln \text { total, } 9}$ articles were identified related to all-ceramic single crowns, 3 of which were on anterior and 6 on posterior 
crowns, and 5 articles on 3-unit FDPs all of which were on posterior FDPs. In the selected 14 articles, a total of 43 experimental subgroups were identified where fracture strength results were reported in N. After data analysis, 50 articles were excluded and the main reasons were due to lack of initial fracture load, , $^{1,2,3,8,10,12,13,15,26,29,30,32,35,37,41-43,45-47,49-53}$ final fracture load, $2,6,9,10,14,15,19,20,25,27,29,30,39,40,47,54,48,60-63,71$ initial and final fracture load (only fatigue survival), 2,10,15,29,30,47,54,58 different units such as $\mathrm{N}$ and $\mathrm{kg}$ in one study, ${ }^{1,2,9,12}$ step-stress loading without initial loading data, ${ }^{14,27,61,63,64}$ not-anatomic crowns $^{22}$ and the use of monolithic restorations only. $4.17,29,72$ (Supplement 1). ${ }^{1-4,6,8-10,12-15,17,19,20,22,25-27,29,30,32,35,37,39,40-43,45-47,49-54,58,60-}$ $65,68-72$

Fatigue cycles varied between minimum of 1000 to maximum 1.200 .000 cycles for crowns and 10.000 to 2.000.000 cycles for 3-unit FDPs (Tables 1a-b). The applied force during cyclic loading varied between 0 to $300 \mathrm{~N}$ for the 3-unit FDPs and 49 to $200 \mathrm{~N}$ for crowns showing great deviation between or within studies. Furthermore, loading was performed with stainless steel indenters having diameters from $6 \mathrm{~mm}$ to $10 \mathrm{~mm}$. Similarly, for the test of the crowns, loading indenters ranged from $1.3 \mathrm{~mm}$ to $4 \mathrm{~mm}$ showing a huge deviation. Load magnitude ranged between 0 to $300 \mathrm{~N}$ during cyclic loading.

There were altogether 5 studies selected for the 3-unit FDPs. Such studies are usually costly and the number of these studies was less than those of studies on crowns $(n=9)$. The number of experimental groups for the FDPs was 10 , and the materials ranged from zirconia $(n=5)$ to sintered alumina $(n=2)$ or lithium disilicate ceramic $(n=3)$. The temperature of the fatigue chambers ranged between 5 and $65^{\circ} \mathrm{C}$.

For the 3-unit FDPs, fracture strength results showed slightly decreased values after cyclic loading

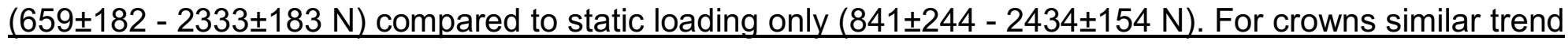
could not be observed but cyclic loading decreased the fracture strength in only some materials after cyclic loading $(659 \pm 182-2333 \pm 183 \mathrm{~N})$ compared to static loading only $(395 \pm 96-2726 \mathrm{~N})$. 


\section{Discussion}

Cyclic fatigue loading test intend to investigate the mechanical durability of dental reconstruction materials prior to clinical trials in order to avoid costly interventions upon failures. One of the main causes of structural failure in restorative dentistry is fatigue. Although static fracture tests may help to screen the durability of FDPs, cyclic loading could be considered a more clinically relevant testing approach. It has been reported that dental restorations fail more frequently under cyclic loading tests that are well below the ultimate flexural strength of these materials as opposed to the application of a single, relatively higher static load. ${ }^{7}$ This systematic review therefore investigated the aging effect of cyclic fatigue tests on mechanical durability of all-ceramic single crowns and FDPs.

One major problem during the search process was the lack of MeSH terms related to cyclic loading or other fatigue related terms. In the dental literature a great number of different terms are being used in order to describe some mechanical aging procedures for reconstructive materials. This issue needs to be solved primarily so that future studies could report on identical search terms. Furthermore, in order to investigate the aging effect of cyclic loading on the durability on FDP materials, the materials should be tested with and without exposure to cyclic loading. Unfortunately, the main reason for exclusion was because the effect of aging could not be identified since no control groups were available presenting the initial fracture load values without fatigue conditions. Focusing only on the final fracture strength after cyclic fatigue loading would not allow for identifying the aging effect of cyclic loading. ${ }_{.}^{1,2,3,8,10,12,13,15,26,29,30,32,35,37,41-43,45-47,49-53}$

The parameters employed by the investigators such as the number of fatigue cycles, loading jigs, frequency of loading, presence of humid environment, involvement of hydrothermal aging conditions showed a great variation in the current dental literature. Furthermore, loading was performed with stainless steel indenters having diameters ranging from 6 to $10 \mathrm{~mm}$ and in some articles, the diameter of the loading iig or indenter was not enclosed. $2,6,9,10,13,15,25,29,35,53,54,59$ In fact, cone crack or Herzian crack formation is highly dependent on the diameter and sharpness of the indenter. ${ }^{38}$ Thus, the type and size of the indenter 
could offset the real aging effect after cyclic loading. In addition, load magnitude ranged between 0 to 300 $\underline{N}$ during cyclic loading. The impact of high loading forces could influence the results and decrease the fatigue resistance. At least in all fatigue studies, the temperature of the fatigue chambers ranged between 5 and $65^{\circ} \mathrm{C}$ which was probably the only parameter kept similar between the studies. Thus, temperature and medium related corrosion process could be considered similar between the selected articles.

Nevertheless, the ultimate goal in measuring load-bearing capacity of materials is to know clinically whether they could endure chewing forces. Different testing methods and the difficulty in measuring masticatory forces result in a wide range of force values. Stress applied during mastication may range between $441 \mathrm{~N}$ and $981 \mathrm{~N}, 245 \mathrm{~N}$ and $491 \mathrm{~N}, 147 \mathrm{~N}$ and $368 \mathrm{~N}$, and $98 \mathrm{~N}$ and $270 \mathrm{~N}$ in the molar, premolar, canine, and incisor regions, respectively. ${ }^{7}$ A restoration should be able to withstand stress to approximately $500 \mathrm{~N}$ in the premolar region and $500 \mathrm{~N}$ to $900 \mathrm{~N}$ in the molar region. The results of this study indicated values higher than $659 \mathrm{~N}^{11}$ for 3-unit FDPs after aging. Similarly for the crowns, the lowest value was $437 \mathrm{~N}$ for feldspathic ceramic ${ }^{57}$ and $>600 \mathrm{~N}^{33,56}$ for high strength ceramics after 1.200 .000 cycles. Certainly, glassy matrix ceramics and in this case feldspathic ceramic that presented $437 \mathrm{~N}$ are not indicated for posterior crowns but for comparison, the authors involved this material in the experimental design. Based on the high results above the estimated chewing forces, current all-ceramic systems could be designated as favourable materials for posterior indications.

It has to be noted that the numbers of cycles varied significantly between studies, namely ranging between minimum $1000^{66}$ cycles to maximum 2.000 .000 cycles. ${ }^{11}$ In fact static loading after limited number of cyclic loading alone could not single out the real effect of aging procedures.

The studies on in vitro FDP systems in the dental literature practiced cycling times ranging from minimum $100^{\times}$to maximum $28 \times 10^{6} .{ }^{48}$ It has been previously reported that $2 \times 10^{6}$ cycles correspond to approximately four years of normal occlusal and masticatory activity. ${ }^{7}$ The load applied also showed variations between 0 to $300 \mathrm{~N}$ in the included articles. ${ }^{48-54}$ On the other hand, from the technical point of view, the magnitude of the applied load with regard to the highest-level force in a fatigue test, should not exceed $50 \%$ of the 
ultimate strength of the material on trial. ${ }^{\bar{x}}$ Unfortunately, ultimate stress information was often not available in the selected articles that performed static loading after fatigue. Therefore, future studies should incorporate the fatigue component in the study set-up in order to deduce more clinically relevant information considering the ultimate strength of the material to be tested after fatigue.

$\underline{\text { In limited number of articles, step-stress fatigue approach was practiced where cyclic load was applied in }}$ such a manner that 3 profiles of loading from mild to aggressive was applied on the single crowns from $100 \mathrm{~N}$ to $750 \mathrm{~N}$ with the mission of completion of 100.000 to 170.000 cycles $^{14,27,61,63,64}$ The load indenter moved sliding from lingual down to buccal being different than in other studies where loading was performed vertically, approaching the occlusal surface. In fact, such an aging method would deliver important information if the results were complete with both initial and final fracture values. At this moment, standards are lacking as regards to dynamics fatigue tests for single crowns and FDP materials. In this regard, ISO $14801^{28}$ assigned for dynamic fatigue test for endosseous dental implants could be implemented in testing fatigue properties of FDPs, providing that implant-borne single crowns are loaded in this norm under an angle of $30 \pm 2^{\circ}$ at $>2 \mathrm{~Hz}$ for $5 \times 10^{6}$ cycles. The clinical relevancy of such testing standards have also not been verified yet. ${ }^{27}$ Nevertheless, such a standard method in tooth-borne FDPs would at least help for ranking mechanical durability of FDPs materials.

In this systematic review only bilayered ceramic systems were investigated. In some articles after fatigue even increased strength values were reported. ${ }^{11,58}$ One important aspect here is that the results after the fracture of the veneering ceramic was not differentiated from the overall fracture strength. Thus, it was not possible to identify whether the loading process was continued until the framework material was fractured. If this is the case and we assume that the reported value does not belong to the principle force to fracture the veneering ceramic in the bilayered assembly. In fact, failure type analysis could have identified where whether the magnitude of force belongs to the veneering material or the core. In a previous study, the changes in energy levels revealed small failures occurring between $300 \mathrm{~N}$ to $500 \mathrm{~N}$ and continuing until 
final failure occurred. ${ }^{44}$ Future studies should identify and report failures in a more systematic way perhaps also using acoustic emission ( $\mathrm{AE})$ signals from the material. ${ }^{44}$

There are several other parameters that could have played further role in fatigue resistance of FDPs such as periodontal ligament, abutment material and the cement. These parameters were not taken into consideration in this review as the principle parameters already showed much heterogeneity. Whether such parameters affect the fatigue resistance of the all-ceramics for crown and FDPs needs further focus in future studies.

Clinically sufficient fracture strength values are not known for durable FDPs. The great variation in testing parameters and testing environment would continue to create the confusion in the dental literature. Since in the future, new studies are expected to appear in this field, the following items should be disclosed in in vitro studies:

- The dimensions of the single crown or FDP, abutment type, abutment material, cement type and its chemical composition, loading conditions (jig dimensions, type, cross-head speed, indenter type, diameter), cyclic loading conditions (medium, temperature, loading magnitude, speed, number of cycles) should be defined precisely.

- The fracture strength data should be presented with confidence intervals, mean, minimum and maximum values with and without cyclic loading together with initial and maximum fracture strength values.

- At least 6 specimens should be tested in one experimental group.

- Failure types after fracture test should be listed in detail and preferably fractography should be performed. 


\section{Conclusion}

From this study, the following could be concluded:

1. Current studies regarding the fatigue strength of single crowns and FDPs made of all-ceramic materials should be evaluated cautiously considering testing conditions. Some more systematic approach especially regarding the testing and reporting fatigue and loading conditions is needed when studying fatigue strength of such reconstructions.

2. Cyclic fatigue tests showed tendencies for decreased results for all-ceramic single crowns and 3-unit FDPs but the effect generally varied depending on the material type and the number of cycles and loading conditions. Yet, the results were often higher than generally accepted chewing forces for the posterior region. 


\section{References}

1. Aboushelib MN: Fatigue and fracture resistance of zirconia crowns prepared with different finish line designs. J Prosthodont 2012;21:22-7.

2. Aboushelib MN: Simulation of cumulative damage associated with long term cyclic loading using a multilevel strain accommodating loading protocol. Dent Mater 2013;29:252-8.

3. Alhasanyah A, Vaidyanathan TK, Flinton RJ: Effect of core thickness differences on post-fatigue indentation fracture resistance of veneered zirconia crowns. J Prosthodont 2013;22:383-90.

4. Attia A, Abdelaziz KM, Freitag S, et al: Fracture load of composite resin and feldspathic all-ceramic CAD/CAM crowns. J Prosthet Dent 2006;95:117-23.

5. Attia A, Kern M: Influence of cyclic loading and luting agents on the fracture load of two all-ceramic crown systems. J Prosthet Dent 2004;92:551-6.

6. Azer SS, Drummond JL, Campbell SD, et al: Influence of core buildup material on the fatigue strength of an all-ceramic crown. J Prosthet Dent 2001;86:624-31.

7. Baldissara P, Özcan M, Melilli D, et al: Effect of cyclic loading on fracture strength and microleakage of a quartz fiber dowel with different adhesive, cement and resin core material combinations. Minerva Stomatol $2010 ; 59,: 407-14$.

8. Behr $M$, Rosentritt $M$, Mangelkramer $M$, et al: The influence of different cements on the fracture resistance and marginal adaptation of all-ceramic and fiber-reinforced crowns. Int $\mathrm{J}$ Prosthodont 2003;16:538-42.

9. Belli R, Frankenberger R, Appelt A, et al: Thermal-induced residual stresses affect the lifetime of zirconia-veneer crowns. Dent Mater 2013;29:181-90.

10. Belli R, Petschelt A, Lohbauer U: Thermal-induced residual stresses affect the fractographic patterns of zirconia-veneer dental prostheses. J Mech Behav Biomed Mater 2013;21:167-77.

11. Beuer F, Steff B, Naumann M, et al: Load-bearing capacity of all-ceramic three-unit fixed partial dentures with different computer-aided design (CAD)/computer-aided manufacturing (CAM) fabricated framework materials. Eur J Oral Sci 2008;116:381-6. 
12. Beuer F, Stimmelmayr M, Gueth JF, et al: In vitro performance of full-contour zirconia single crowns. Dent Mater 2012;28:449-56.

13. Blatz MB, Oppes S, Chiche G, et al: Influence of cementation technique on fracture strength and leakage of alumina all-ceramic crowns after cyclic loading. Quintessence Int 2008;39:23-32.

14. Bonfante EA, Rafferty B, Zavanelli RA, et al: Thermal/mechanical simulation and laboratory fatigue testing of an alternative yttria tetragonal zirconia polycrystal core-veneer all-ceramic layered crown design. Eur J Oral Sci 2010;118:202-9.

15. Bonfante EA, Sailer I, Silva NR, et al: Failure modes of Y-TZP crowns at different cusp inclines. J Dent 2010;38:707-12.

16. Borges GA, Caldas D, Taskonak B, et al: Fracture loads of all-ceramic crowns under wet and dry fatigue conditions. J Prosthodont 2009;18:649-55.

17. Chen HY, Hickel R, Setcos JC, et al: Effects of surface finish and fatigue testing on the fracture strength of CAD-CAM and pressed-ceramic crowns. J Prosthet Dent 1999;82:468-75.

18. Chitmongkolsuk S, Heydecke G, Stappert C, et al: Fracture strength of all-ceramic lithium disilicate and porcelain-fused-to-metal bridges for molar replacement after dynamic loading. Eur J Prosthodont Restor Dent 2002;10:15-22.

19. Coelho PG, Bonfante EA, Silva NR, et al: Laboratory simulation of Y-TZP all-ceramic crown clinical failures. J Dent Res 2009;88:382-6.

20. Coelho PG, Silva NR, Bonfante EA, et al: Fatigue testing of two porcelain-zirconia all-ceramic crown systems. Dent Mater 2009;25:1122-7.

21. Coray R, Zeltner $M$, Özcan $M$ : Fracture strength of implant abutments after fatigue testing: $A$ systematic review and a meta-analysis. J Mech Behav Biomed Mater 2016;14;62:333-346.

22. Corazza PH, Feitosa SA, Borges AL, et al: Influence of convergence angle of tooth preparation on the fracture resistance of Y-TZP-based all-ceramic restorations. Dent Mater 2013;29:339-47.

23. DIN EN ISO 22674 norm. Metallic materials for fixed and removable restorations and application, DIN, German Institute for norming. 2006. 
24. Eroglu Z, Gurbulak AG: Fatigue behavior of zirconia-ceramic, galvano-ceramic, and porcelain-fused-tometal fixed partial dentures. J Prosthodont 2013;22:516-22.

25. Gresnigt MM, Özcan M, Kalk W, et al: Effect of static and cyclic loading on ceramic laminate veneers adhered to teeth with and without aged composite restorations. J Adhes Dent 2011;13:569-77.

26. Guess PC, Bonfante EA, Silva NR, et al: Effect of core design and veneering technique on damage and reliability of Y-TZP-supported crowns. Dent Mater 2013;29:307-16.

27. Guess PC, Zavanelli RA, Silva NR, et al: Monolithic CAD/CAM lithium disilicate versus veneered YTZP crowns: comparison of failure modes and reliability after fatigue. Int J Prosthodont 2010;23:434-42.

28. ISO 14801. Fatigue Test for Endosseous Dental Implants. Geneva: International Organization for Standardization, 2007.

29. Kassem AS, Atta O, El-Mowafy O: Combined effects of thermocycling and load-cycling on microleakage of computer-aided design/computer-assisted manufacture molar crowns. Int J Prosthodont 2011;24:376-8.

30. Kassem AS, Atta O, El-Mowafy O: Fatigue resistance and microleakage of CAD/CAM ceramic and composite molar crowns. J Prosthodont 2012;21:28-32.

31. Kelly JR, Benetti $P$, Rungruanganunt $P$, et al: The slippery slope: critical perspectives on in vitro research methodologies. Dent Mater 2012;28:41-51.

32. Kheradmandan S, Koutayas SO, Bernhard M, et al: Fracture strength of four different types of anterior 3-unit bridges after thermo-mechanical fatigue in the dual-axis chewing simulator. $\mathrm{J}$ Oral Rehabil 2001;28:361-9.

33. Kim JH, Park JH, Park YB, et al: Fracture load of zirconia crowns according to the thickness and marginal design of coping. J Prosthet Dent 2012;108:96-101.

34. Kohorst P, Dittmer MP, Borchers $L$, et al: Influence of cyclic fatigue in water on the load-bearing capacity of dental bridges made of zirconia. Acta Biomater 2008;4:1440-7. 
35. Kolbeck C, Rosentritt M, Handel G: Fracture strength of artificially aged 3-unit adhesive fixed partial dentures made of fiber-reinforced composites and ceramics: an in vitro study. Quintessence Int 2006;37:731-5.

36. Komine F, Tomic M, Gerds $\mathrm{T}$, et al: Influence of different adhesive resin cements on the fracture strength of aluminum oxide ceramic posterior crowns. J Prosthet Dent 2004;92:359-64.

37. Larsson C, Holm L, Lovgren N, et al: Fracture strength of four-unit Y-TZP FPD cores designed with varying connector diameter. An in-vitro study. J Oral Rehabil 2007;34:702-9.

38. Lawn BR, Deng Y, Thompson VP: Use of contact testing in the characterization and design of allceramic crownlike layer structures: a review. J Prosthet Dent 2001;86:495-510.

39. Lorenzoni FC, Martins LM, Silva NR, et al: Fatigue life and failure modes of crowns systems with a modified framework design. J Dent 2010;38:626-34.

40. Mormann W, Wolf D, Ender A, et al: Effect of two self-adhesive cements on marginal adaptation and strength of esthetic ceramic CAD/CAM molar crowns. J Prosthodont 2009;18:403-10.

41. Mahmood DJ, Linderoth EH, Vult Von Steyern P: The influence of support properties and complexity on fracture strength and fracture mode of all-ceramic fixed dental prostheses. Acta Odontol Scand 2011;69:229-37.

42. Ohlmann B, Dittmar A, Rues S, et al: Comparison of fracture-load values of cantilevered FDPs. Acta Odontol Scand 2013;71:584-9.

43. Okutan M, Heydecke G, Butz F, et al: Fracture load and marginal fit of shrinkage-free ZrSiO4 allceramic crowns after chewing simulation. J Oral Rehabil 2006;33:827-32.

44. Özcan M, Breuklander MH, Vallittu PK: The effect of box preparation on the strength of glass fiberreinforced composite inlay-retained fixed partial dentures. J Prosthet Dent 2005;93:337-45.

45. Preis $\mathrm{V}$, Behr M, Hahnel $\mathrm{S}$, et al: In vitro failure and fracture resistance of veneered and full-contour zirconia restorations. J Dent 2012;40:921-8.

46. Preis V, Letsch C, Handel G, et al: Influence of substructure design, veneer application technique, and firing regime on the in vitro performance of molar zirconia crowns. Dent Mater 2013;29:e113-21. 
47. Rekow ED, Zhang G, Thompson V, et al: Effects of geometry on fracture initiation and propagation in all-ceramic crowns. J Biomed Mater Res B Appl Biomater 2009;88:436-46.

48. Rosentritt M, Behr M, Leibrock A, et al: Intraoral repair of fiber-reinforced composite fixed partial dentures. J Prosthet Dent 1998;79:393-8.

49. Rosentritt M, Behr M, Gebhard R, et al: Influence of stress simulation parameters on the fracture strength of all-ceramic fixed-partial dentures. Dent Mater 2006;22:176-82.

50. Rosentritt M, Behr M, Scharnagl P, et al: Influence of resilient support of abutment teeth on fracture resistance of all-ceramic fixed partial dentures: an in vitro study. Int J Prosthodont 2011;24:465-8.

51. Rosentritt M, Kolbeck C, Handel G, et al: Influence of the fabrication process on the in vitro performance of fixed dental prostheses with zirconia substructures. Clin Oral Investig 2011;15:1007-12.

52. Rosentritt $\mathrm{M}$, Plein $\mathrm{T}$, Kolbeck $\mathrm{C}$, et al: In vitro fracture force and marginal adaptation of ceramic crowns fixed on natural and artificial teeth. Int J Prosthodont 2000;13:387-91.

53. Rosentritt M, Siavikis G, Behr M, et al: Approach for valuating the significance of laboratory simulation. J Dent 2008;36:1048-53.

54. Rosentritt M, Steiger D, Behr M, et al: Influence of substructure design and spacer settings on the in vitro performance of molar zirconia crowns. J Dent 2009;37:978-83.

55. Rues S, Kräger E, Müller D, et al: Effect of firing protocols on cohesive failure of all-ceramic crowns. J Dent 2010;38:987-94.

56. Schmitter M, Mueller D, Rues S: Chipping behaviour of all-ceramic crowns with zirconia framework and CAD/CAM manufactured veneer. J Dent 2012;40:154-62.

57. Schmitter M, Mueller D, Rues S: In vitro chipping behaviour of all-ceramic crowns with a zirconia framework and feldspathic veneering: comparison of CAD/CAM-produced veneer with manually layered veneer. J Oral Rehabil 2013;40:519-25.

58. Schultheis S, Strub JR, Gerds TA, et al: Monolithic and bi-layer CAD/CAM lithium-disilicate versus metal-ceramic fixed dental prostheses: comparison of fracture loads and failure modes after fatigue. Clin Oral Investig 2013;17:1407-13. 
59. Senyilmaz DP, Canay S, Heydecke G, et al: Influence of thermomechanical fatigue loading on the fracture resistance of all-ceramic posterior crowns. Eur J Prosthodont Restor Dent 2010;18:50-4.

60. Silva NR, Bonfante E, Rafferty BT, et al: Conventional and modified veneered zirconia vs. metalloceramic: fatigue and finite element analysis. J Prosthodont 2012;21:433-9.

61. Silva NR, Bonfante EA, Rafferty BT, et al: Modified Y-TZP core design improves all-ceramic crown reliability. J Dent Res 2011;90:104-8.

62. Silva NR, Bonfante EA, Zavanelli RA, et al: Reliability of metalloceramic and zirconia-based ceramic crowns. J Dent Res 2010;89:1051-6.

63. Silva NR, Thompson VP, Valverde GB, et al: Comparative reliability analyses of zirconium oxide and lithium disilicate restorations in vitro and in vivo. J Am Dent Assoc 2011;2:4S-9S.

64. Skouridou N, Pollington S, Rosentritt M, et al: Fracture strength of minimally prepared all-ceramic CEREC crowns after simulating 5 years of service. Dent Mater 2013;29:e70-7.

65. Slavcheva S, Krejci I, Bortolotto T: Luting of ceramic crowns with a self-adhesive cement: effect of contamination on marginal adaptation and fracture strength. Med Oral Patol Oral Cir Bucal 2013;18:e799803.

66. Sobrinho LC, Cattell MJ, Glover RH, et al: Investigation of the dry and wet fatigue properties of three all-ceramic crown systems. Int J Prosthodont 1998;11:255-62.

67. Sobrinho LC, Glover RH, Knowles JC, et al: Comparison of the wet and dry fatigue properties of all ceramic crowns. J Mater Sci Mater Med 1998;9:517-21.

68. Sundh A, Molin M, Sjögren G: Fracture resistance of yttrium oxide partially-stabilized zirconia allceramic bridges after veneering and mechanical fatigue testing. Dent Mater 2005;21:476-82.

69. Tsalouchou E, Cattell MJ, Knowles JC, et al: Fatigue and fracture properties of yttria partially stabilized zirconia crown systems. Dent Mater 2008;24:308-18.

70. Vult von Steyern P, Ebbesson S, Holmgren J, et al: Fracture strength of two oxide ceramic crown systems after cyclic pre-loading and thermocycling. J Oral Rehabil 2006;33:682-9. 
71. Zahran M, El-Mowafy O, Tam L, et al: Fracture strength and fatigue resistance of all-ceramic molar crowns manufactured with CAD/CAM technology. J Prosthodont 2008;17:370-7.

72. Zhao K, Wei YR, Pan Y, et al: Influence of veneer and cyclic loading on failure behavior of lithium disilicate glass-ceramic molar crowns. Dent Mater 2014;30:164-71. 


\section{Captions to figures and tables:}

\section{Figures:}

Fig. 1 Process of identifying the studies included in the review.

\section{Tables:}

Tables 1a-b. Fracture strength of a) crowns, b) 3-unit FDPs made of different all-ceramic materials with and without cyclic loading together with cyclic loading test parameters. 


\section{Figures:}

Potentially relevant journal articles according to the titles after electronic search

$$
n=709
$$

Independent screening by 2 reviewers

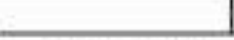

Included abstracts after title screening $n=237$

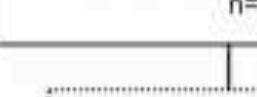

Kappa score: 0.85

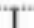

Potentially appropriate downloaded joumal articles to be included in the study after abstract reading

$$
n=109
$$

purnal articles included after hand search

$$
n=0
$$

Excluded journal articles irrelevant to the study objectives after full text screening

$$
n=45
$$

Joumal articles included for data analysis $N=64$

Joumal articles excluded after data analysis

$n=50$

Joumal articles included for the final analysis

$$
\mathrm{N}=14
$$

Fig. 1 Process of identifying the studies included in the review. 
Tables: 


\begin{tabular}{|c|c|c|c|c|c|c|c|c|c|c|}
\hline Author & $\begin{array}{c}\text { Framework } \\
\text { ceramic }\end{array}$ & $\begin{array}{l}\text { Veneering } \\
\text { ceramic }\end{array}$ & $\begin{array}{c}\text { Locatio } \\
\mathbf{n}\end{array}$ & $\begin{array}{c}\text { Fracture } \\
\text { strength }(\mathbf{N}) \\
\text { before fatigue }\end{array}$ & \begin{tabular}{|c|} 
Fatigue \\
condition \\
$s$
\end{tabular} & & & & $\begin{array}{l}\text { Fracture } \\
\text { strength } \\
\text { (N) after } \\
\text { fatigue } \\
\end{array}$ & \\
\hline & & & & & $\begin{array}{l}\text { Number } \\
\text { of Cycles }\end{array}$ & $\begin{array}{l}\text { Force } \\
(\mathrm{N})\end{array}$ & Temperature & Indenter & & Indenter \\
\hline \multirow[t]{2}{*}{$\begin{array}{l}\text { Schmitter } \\
\text { M et al. }{ }^{56} \\
\end{array}$} & $\begin{array}{c}\text { Zirconia } \\
\text { (Sirona in } \\
\text { Coris UI, } \\
\text { mono L F1) }\end{array}$ & $\begin{array}{l}\text { Lithiumdisilicat } \\
\text { e ceramic (IPS } \\
\text { e.max CAD, } \\
\text { Crystall/Connec } \\
\text { t) }\end{array}$ & posterior & $\begin{array}{c}F 1 d=1253 \pm 400 \\
F u 1565 \pm 137\end{array}$ & $1.2 \times 10^{6}$ & $\begin{array}{l}\max \\
108\end{array}$ & $6.5-60$ & $\begin{array}{l}6 \mathrm{~mm} \\
\text { steel } \\
\text { sphere }\end{array}$ & $\begin{array}{c}F 1 d= \\
1234 \pm 512 \\
F u= \\
1642 \pm 420\end{array}$ & $\begin{array}{c}6 \mathrm{~mm} \\
\text { steel } \\
\text { sphere }\end{array}$ \\
\hline & $\begin{array}{c}\text { Zirconia } \\
\text { (Sirona in } \\
\text { Coris UI, } \\
\text { mono L F1) } \\
\end{array}$ & $\begin{array}{l}\text { Conventional } \\
\text { veneering } \\
\text { porcelain } \\
\end{array}$ & posterior & $\begin{array}{l}F 1 d=503 \pm 217 \\
F u=1166 \pm 189\end{array}$ & $1.2 \times 10^{6}$ & $\begin{array}{l}\max \\
108\end{array}$ & $6.5-60$ & $\begin{array}{c}6 \mathrm{~mm} \\
\text { steel } \\
\text { sphere }\end{array}$ & $\begin{array}{l}F 1 d=934 \\
F u=934\end{array}$ & $\begin{array}{c}6 \mathrm{~mm} \\
\text { steel } \\
\text { sphere }\end{array}$ \\
\hline \multirow[t]{6}{*}{$\begin{array}{l}\text { Sobrinho } \\
\text { LC et al. }{ }^{67}\end{array}$} & $\begin{array}{c}\text { (IPS } \\
\text { Empress) }\end{array}$ & & posterior & $1256 \pm 84$ & 10.000 & $20-300$ & n.a. & n.a. & $1156 \pm 87$ & $\begin{array}{c}4 \mathrm{~mm} \\
\text { steel ball }\end{array}$ \\
\hline & $\begin{array}{c}\text { (IPS } \\
\text { Empress) }\end{array}$ & & posterior & $1256 \pm \$ 84$ & 10.000 & $20-300$ & n.a. & n.a. & $1075 \pm 136$ & $\begin{array}{c}4 \mathrm{~mm} \\
\text { steel ball }\end{array}$ \\
\hline & $\begin{array}{c}\text { (OPC Jeneric } \\
\text { Pentron) }\end{array}$ & & posterior & $997 \pm 200$ & 10.000 & $20-300$ & n.a. & n.a. & $924 \pm 151$ & $\begin{array}{c}4 \mathrm{~mm} \\
\text { steel ball }\end{array}$ \\
\hline & \begin{tabular}{|c|} 
(OPC Jeneric \\
Pentron)
\end{tabular} & & posterior & $997 \pm 200$ & 10.000 & $20-300$ & n.a. & n.a. & $843 \pm 149$ & $\begin{array}{c}4 \mathrm{~mm} \\
\text { steel ball }\end{array}$ \\
\hline & In-Ceram & $\begin{array}{c}\text { Porcelain (Vita } \\
\text { Alpha, Dentine } \\
\text { porcelain) }\end{array}$ & posterior & $817 \pm 96$ & 10.000 & $20-300$ & n.a. & n.a. & $756 \pm 169$ & $\begin{array}{c}4 \mathrm{~mm} \\
\text { steel ball }\end{array}$ \\
\hline & In-Ceram & $\begin{array}{c}\text { Porcelain (Vita } \\
\text { Alpha, Dentine } \\
\text { porcelain) }\end{array}$ & posterior & $817 \pm 96$ & 10.000 & $20-300$ & n.a. & n.a. & $663 \pm 114$ & $\begin{array}{c}4 \mathrm{~mm} \text { steel } \\
\text { ball }\end{array}$ \\
\hline \multirow[t]{2}{*}{$\begin{array}{l}\text { Rues S } \\
\text { et al. }{ }^{55}\end{array}$} & \begin{tabular}{|c} 
Zirconia \\
(Ceron Base \\
DeguDent, \\
Hanau, \\
Germany \\
\end{tabular} & $\begin{array}{c}\text { (Ceron Ceram } \\
\text { Kiss) }\end{array}$ & anterior & $\begin{array}{c}F 1 d=314 \pm 167 \\
F u=481 \pm 178\end{array}$ & $1.2 \times 10^{6}$ & 86 & $6.5-65$ & $\begin{array}{c}3 \mathrm{~mm} \\
\text { steel ball }\end{array}$ & $\begin{array}{c}\mathrm{F} 1 \mathrm{~d}= \\
142 \pm 94 \\
\mathrm{Fu}= \\
153 \pm 97\end{array}$ & $\begin{array}{c}1.6 \mathrm{~mm} \\
\text { steel ball }\end{array}$ \\
\hline & $\begin{array}{c}\text { Zirconia } \\
\text { (Ceron Base }\end{array}$ & $\begin{array}{c}\text { (Ceron Ceram } \\
\text { Love) }\end{array}$ & anterior & $\begin{array}{l}F 1 d=314 \pm 167 \\
F u=481 \pm 178\end{array}$ & $1.2 \times 10^{6}$ & 86 & $6.5-65$ & $\begin{array}{c}3 \mathrm{~mm} \\
\text { steel ball }\end{array}$ & $\begin{array}{c}F 1 d= \\
255 \pm 228\end{array}$ & $\begin{array}{c}1.6 \mathrm{~mm} \\
\text { steel ball }\end{array}$ \\
\hline
\end{tabular}




\begin{tabular}{|c|c|c|c|c|c|c|c|c|c|c|}
\hline & $\begin{array}{c}\text { DeguDent, } \\
\text { Hanau, } \\
\text { Germany }\end{array}$ & & & & & & & & $\begin{array}{c}F u= \\
258 \pm 228\end{array}$ & \\
\hline & $\begin{array}{c}\text { Zirconia } \\
\text { (Ceron Base } \\
\text { DeguDent, } \\
\text { Hanau, } \\
\text { Germany } \\
\end{array}$ & $\begin{array}{l}\text { (Ceron Ceram } \\
\text { Kiss) }\end{array}$ & anterior & $\begin{array}{l}F 1 d=410 \pm 212 \\
F u=641 \pm 155\end{array}$ & $1.2 \times 10^{6}$ & 86 & $6.5-65$ & $\begin{array}{c}3 \mathrm{~mm} \\
\text { steel ball }\end{array}$ & $\begin{array}{c}F 1 d= \\
218 \pm 94 \\
F u= \\
263 \pm 126\end{array}$ & $\begin{array}{c}1.6 \mathrm{~mm} \\
\text { steel ball }\end{array}$ \\
\hline & \begin{tabular}{|c} 
Zirconia \\
(Ceron Base \\
DeguDent, \\
Hanau, \\
Germany \\
\end{tabular} & $\begin{array}{c}\text { (Ceron Ceram } \\
\text { Love) }\end{array}$ & anterior & $\begin{array}{l}F 1 d=410 \pm 212 \\
F u=641 \pm 155\end{array}$ & $1.2 \times 10^{6}$ & 86 & $6.5-65$ & $\begin{array}{c}3 \mathrm{~mm} \\
\text { steel ball }\end{array}$ & $\begin{array}{c}F 1 d= \\
315 \pm 260 \\
F u= \\
331 \pm 279\end{array}$ & $\begin{array}{r}1.6 \mathrm{~mm} \\
\text { steel ball }\end{array}$ \\
\hline \multirow[t]{2}{*}{$\begin{array}{l}\text { Kim JH } \\
\text { et al. }^{33}\end{array}$} & $\begin{array}{c}\text { Zirconia } \\
\text { (Ceron Base } \\
\text { Dentsply } \\
\text { Prosthetics) }\end{array}$ & $\begin{array}{l}\text { Ceramic (IPS } \\
\text { e.max Ceram, } \\
\text { Ivoclar } \\
\text { Vivadent, } \\
\text { Schaan, } \\
\text { Liechtenstein) }\end{array}$ & anterior & $2126.9 \pm 576.9$ & 6.000 & $0-200$ & n.a. & $\begin{array}{c}15 \mathrm{~mm} \\
\text { stainsless } \\
\text { steel } \\
\text { cylinder } \\
\end{array}$ & $\begin{array}{c}1366.1 \pm 51 \\
9.1 \\
\end{array}$ & $\begin{array}{c}3 \mathrm{~mm} \\
\text { stainless } \\
\text { steel } \\
\text { hemiphere }\end{array}$ \\
\hline & $\begin{array}{c}\text { Zirconia } \\
\text { (Ceron Base } \\
\text { Dentsply } \\
\text { Prosthetics) } \\
\end{array}$ & $\begin{array}{c}\text { Ceramic (IPS } \\
\text { e.max Ceram, } \\
\text { Ivoclar } \\
\text { Vivadent) }\end{array}$ & anterior & $2329.1 \pm 948.3$ & 6.000 & $0-200$ & n.a. & $\begin{array}{c}15 \mathrm{~mm} \\
\text { stainsless } \\
\text { steel } \\
\text { cylinder } \\
\end{array}$ & $\begin{array}{c}1232.82 \pm 4 \\
03.8 \\
\end{array}$ & $\begin{array}{c}3 \mathrm{~mm} \\
\text { stainless } \\
\text { steel } \\
\text { hemiphere }\end{array}$ \\
\hline \multirow[t]{4}{*}{$\begin{array}{l}\text { Borges } \\
\text { GA et } \\
\text { al. }^{16} \\
\end{array}$} & $\begin{array}{c}\text { (InCeram } \\
\text { Alumina, Vita } \\
\text { Zahnfabrik) }\end{array}$ & $\begin{array}{c}\text { Porcelain } \\
\text { (Vitadur Alpha } \\
\text { Porcelain, } \\
\text { Vivadent, } \\
\text { Germany) } \\
\end{array}$ & anterior & $1528 \pm 238$ & 6.000 & $20-300$ & n.a. & n.a. & $1111 \pm 198$ & $\begin{array}{c}4 \mathrm{~mm} \\
\text { stainless } \\
\text { steel ball } \\
\end{array}$ \\
\hline & $\begin{array}{c}\text { (InCeram } \\
\text { Alumina, Vita } \\
\text { Zahnfabrik) }\end{array}$ & $\begin{array}{c}\text { Porcelain } \\
\text { (Vitadur Alpha } \\
\text { Porcelain) }\end{array}$ & anterior & $1528 \pm 238$ & 6.000 & $20-300$ & n.a. & n.a. & $843 \pm 80$ & $\begin{array}{c}4 \mathrm{~mm} \\
\text { stainless } \\
\text { steel ball }\end{array}$ \\
\hline & $\begin{array}{c}\text { (IPS } \\
\text { Empress 2, } \\
\text { Ivoclar) }\end{array}$ & $\begin{array}{c}\text { Porcelain } \\
\text { (D'Sign, Ivoclar) }\end{array}$ & anterior & $1412 \pm 153$ & 6.000 & $20-300$ & n.a. & n.a. & $1071 \pm 75$ & $\begin{array}{c}4 \mathrm{~mm} \\
\text { stainless } \\
\text { steel ball }\end{array}$ \\
\hline & $\begin{array}{c}\text { (IPS } \\
\text { Empress 2, } \\
\text { Ivoclar) }\end{array}$ & $\begin{array}{c}\text { Porcelain } \\
\text { (D'Sign, Ivoclar) }\end{array}$ & anterior & $1412 \pm 153$ & 6.000 & $20-300$ & n.a. & n.a. & $895 \pm 56$ & \begin{tabular}{|c|}
$4 \mathrm{~mm}$ \\
stainless \\
steel ball
\end{tabular} \\
\hline
\end{tabular}




\begin{tabular}{|c|c|c|c|c|c|c|c|c|c|c|}
\hline & Cergogold & $\begin{array}{l}\text { Porcelain } \\
\text { (Duceragold, } \\
\text { Degussa } \\
\text { Dental) }\end{array}$ & anterior & $947 \pm 144$ & 60.000 & $20-300$ & n.a. & n.a. & $698 \pm 201$ & $\begin{array}{l}4 \mathrm{~mm} \\
\text { stainless } \\
\text { steel ball }\end{array}$ \\
\hline & Cergogold & $\begin{array}{l}\text { Porcelain } \\
\text { (Duceragold) }\end{array}$ & anterior & $947 \pm 144$ & 60.000 & $20-300$ & n.a. & n.a. & $585 \pm 200$ & $\begin{array}{c}4 \mathrm{~mm} \\
\text { stainless } \\
\text { steel ball }\end{array}$ \\
\hline & $\begin{array}{c}\text { (InCeram } \\
\text { Alumina, Vita } \\
\text { Zahnfabrik) }\end{array}$ & $\begin{array}{c}\text { Porcelain } \\
\text { (Vitadur Alpha } \\
\text { Porcelain, } \\
\text { Vivadent, } \\
\text { Germany) }\end{array}$ & anterior & $1182 \pm 203$ & 60.000 & $20-300$ & n.a. & n.a. & $926 \pm 127$ & $\begin{array}{c}4 \mathrm{~mm} \\
\text { stainless } \\
\text { steel ball }\end{array}$ \\
\hline & $\begin{array}{c}\text { (InCeram } \\
\text { Alumina, Vita } \\
\text { Zahnfabrik) }\end{array}$ & $\begin{array}{l}\text { Porcelain } \\
\text { (Vitadur Alpha } \\
\text { Porcelain) }\end{array}$ & anterior & $1182 \pm 203$ & 60.000 & $20-300$ & n.a. & n.a. & $710 \pm 122$ & $\begin{array}{c}4 \mathrm{~mm} \\
\text { stainless } \\
\text { steel ball }\end{array}$ \\
\hline & $\begin{array}{c}\text { (IPS } \\
\begin{array}{c}\text { Empress 2, } \\
\text { Ivoclar) }\end{array}\end{array}$ & $\begin{array}{c}\text { Porcelain } \\
\text { (D'Sign, Ivoclar) }\end{array}$ & anterior & $1154 \pm 233$ & 60.000 & $20-300$ & n.a. & n.a. & $868 \pm 67$ & $\begin{array}{c}4 \mathrm{~mm} \\
\text { stainless } \\
\text { steel ball }\end{array}$ \\
\hline & $\begin{array}{c}\text { (IPS } \\
\text { Empress 2, } \\
\text { Ivoclar) }\end{array}$ & $\begin{array}{c}\text { Porcelain } \\
\text { (D'Sign, Ivoclar) }\end{array}$ & anterior & $1154 \pm 233$ & 60.000 & $20-300$ & n.a. & n.a. & $760 \pm 70$ & $\begin{array}{c}4 \mathrm{~mm} \\
\text { stainless } \\
\text { steel ball }\end{array}$ \\
\hline & Cergogold & $\begin{array}{l}\text { Porcelain } \\
\text { (Duceragold, } \\
\text { Degussa } \\
\text { Dental) }\end{array}$ & anterior & $646 \pm 108$ & 60.000 & $20-300$ & n.a. & n.a. & $569 \pm 209$ & $\begin{array}{c}4 \mathrm{~mm} \\
\text { stainless } \\
\text { steel ball }\end{array}$ \\
\hline & Cergogold & $\begin{array}{c}\text { Porcelain } \\
\text { (Duceragold) }\end{array}$ & anterior & $646 \pm 108$ & 60.000 & $20-300$ & n.a. & n.a. & $512 \pm 176$ & $\begin{array}{c}4 \mathrm{~mm} \\
\text { stainless } \\
\text { steel ball }\end{array}$ \\
\hline $\begin{array}{l}\text { Schmitter } \\
\text { M et al. }{ }^{57}\end{array}$ & \begin{tabular}{|c} 
zirconia \\
(mono L F1, \\
Sirona in \\
Coris Zi, \\
Cerec Bloc, \\
Sirona, \\
Bensheim, \\
Germany \\
\end{tabular} & $\begin{array}{c}\text { Feldspathic } \\
\text { ceramic } \\
\text { (Ceramic Bloc) }\end{array}$ & posterior & $395 \pm 96$ & $1.2 \times 10^{6}$ & $\begin{array}{l}\max \\
108\end{array}$ & $6.5-60^{\circ} \mathrm{C}$ & $\begin{array}{l}6 \mathrm{~mm} \\
\text { steel } \\
\text { sphere }\end{array}$ & $437 \pm 35$ & $\begin{array}{l}6 \mathrm{~mm} \\
\text { steel } \\
\text { sphere }\end{array}$ \\
\hline
\end{tabular}




\begin{tabular}{|c|c|c|c|c|c|c|c|c|c|c|}
\hline & \begin{tabular}{|c} 
zirconia \\
(mono L F1, \\
Sirona in \\
Coris Zi, \\
Cerec Bloc, \\
Sirona, \\
Bensheim, \\
Germany
\end{tabular} & $\begin{array}{l}\text { Conventional } \\
\text { veneering } \\
\text { porcelain }\end{array}$ & posterior & $1166 \pm 189$ & $1.2 \times 10^{6}$ & $\begin{array}{l}\max \\
108\end{array}$ & $6.5-60^{\circ} \mathrm{C}$ & $\begin{array}{c}6 \mathrm{~mm} \\
\text { steel } \\
\text { sphere }\end{array}$ & 934 & $\begin{array}{c}6 \mathrm{~mm} \\
\text { steel } \\
\text { sphere }\end{array}$ \\
\hline \multirow[t]{3}{*}{$\begin{array}{c}\text { Attia A. } \\
\text { and Kern } \\
\mathrm{M}^{5}\end{array}$} & \begin{tabular}{|c|} 
Lithium \\
disilicate \\
galss ceramic \\
(IPS Empress \\
2, Ivoclar) \\
\end{tabular} & & posterior & $1007.6 \pm 252.8$ & 6.000 & 49 & $4-58^{\circ} \mathrm{C}$ & $\begin{array}{c}4 \mathrm{~mm} \\
\text { ceramic } \\
\text { ball }\end{array}$ & $\begin{array}{c}861.5 \pm 140 \\
.7 \\
\end{array}$ & $\begin{array}{c}4 \mathrm{~mm} \\
\text { stainless } \\
\text { steel ball }\end{array}$ \\
\hline & \begin{tabular}{|c|} 
Lithium \\
disilicate \\
galss ceramic \\
(IPS Empress \\
2, Ivoclar) \\
\end{tabular} & & posterior & $914.6 \pm 207.3$ & 6.000 & 49 & $4-58^{\circ} \mathrm{C}$ & $\begin{array}{c}4 \mathrm{~mm} \\
\text { ceramic } \\
\text { ball }\end{array}$ & $786 \pm 161.6$ & $\begin{array}{c}4 \mathrm{~mm} \\
\text { stainless } \\
\text { steel ball }\end{array}$ \\
\hline & \begin{tabular}{|c} 
Lithium \\
disilicate \\
galss ceramic \\
(IPS Empress \\
2, Ivoclar) \\
\end{tabular} & & posterior & $928 \pm 210.4$ & 6.000 & 49 & $4-58^{\circ} \mathrm{C}$ & $\begin{array}{c}4 \mathrm{~mm} \\
\text { ceramic } \\
\text { ball }\end{array}$ & $\begin{array}{c}641.2 \pm 179 \\
.2 \\
\end{array}$ & $\begin{array}{c}4 \mathrm{~mm} \\
\text { stainless } \\
\text { steel ball }\end{array}$ \\
\hline \multirow[t]{2}{*}{$\begin{array}{l}\text { Komine } \\
\text { F. et al. }{ }^{36}\end{array}$} & $\begin{array}{c}\text { Glass } \\
\text { infiltrated } \\
\text { aluminium } \\
\text { oxide (In } \\
\text { Ceram } \\
\text { Alumina, vita } \\
\text { Zahnfabrik) } \\
\end{array}$ & $\begin{array}{c}\text { Feldspathic } \\
\text { ceramic (Vita } \\
\text { VM7, Vita } \\
\text { Zahnfabrik) }\end{array}$ & posterior & 2726 & $1.2 \times 10^{6}$ & 49 & $5-55^{\circ} \mathrm{C}$ & $\begin{array}{c}6 \mathrm{~mm} \\
\text { ceramic } \\
\text { ball }\end{array}$ & 2673 & n.a. \\
\hline & \begin{tabular}{|c|} 
Glass \\
infiltrated \\
aluminium \\
oxide (In \\
Ceram \\
Alumina, vita \\
Zahnfabrik)
\end{tabular} & $\begin{array}{c}\text { Feldspathic } \\
\text { ceramic (Vita } \\
\text { VM7, Vita } \\
\text { Zahnfabrik) }\end{array}$ & posterior & 2520 & $1.2 \times 10^{6}$ & 49 & $5-55^{\circ} \mathrm{C}$ & $\begin{array}{c}6 \mathrm{~mm} \\
\text { ceramic } \\
\text { ball }\end{array}$ & 2083 & n.a. \\
\hline
\end{tabular}




\begin{tabular}{|c|c|c|c|c|c|c|c|c|c|c|}
\hline & \begin{tabular}{|c|} 
Glass \\
infiltrated \\
aluminium \\
oxide (In \\
Ceram \\
Alumina, vita \\
Zahnfabrik)
\end{tabular} & $\begin{array}{c}\text { Feldspathic } \\
\text { ceramic (Vita } \\
\text { VM7, Vita } \\
\text { Zahnfabrik) }\end{array}$ & posterior & 2036 & $1.2 \times 10^{6}$ & 49 & $5-55^{\circ} \mathrm{C}$ & $\begin{array}{c}6 \mathrm{~mm} \\
\text { ceramic } \\
\text { ball }\end{array}$ & 2369 & n.a. \\
\hline & $\begin{array}{c}\text { Lithium } \\
\text { disilicate } \\
\text { glass ceramic } \\
\text { (IPS e.max } \\
\text { Press, Ivoclar, } \\
\text { Vivadent) }\end{array}$ & $\begin{array}{l}\text { (IPS e.max } \\
\text { Press, Ivoclar, } \\
\text { Vivadent) }\end{array}$ & posterior & $1442.77 \pm 327.49$ & $1.2 \times 10^{6}$ & 98 & $5-55^{\circ} \mathrm{C}$ & $\begin{array}{c}6 \mathrm{~mm} \\
\text { ceramic } \\
\text { ball }\end{array}$ & $\begin{array}{c}1464.23 \pm 4 \\
18.84\end{array}$ & $\begin{array}{c}6 \mathrm{~mm} \\
\text { ceramic } \\
\text { ball }\end{array}$ \\
\hline \multirow[t]{6}{*}{$\begin{array}{l}\text { Sobrinho } \\
\text { LC et al. }{ }^{66}\end{array}$} & In-Ceram & $\begin{array}{c}\text { Porcelain (Vita } \\
\text { Alpha, Dentine } \\
\text { porcelain) }\end{array}$ & posterior & $1901 \pm 303$ & 1.000 & $20-300$ & n.a. & n.a. & $1601 \pm 198$ & $\begin{array}{c}4 \mathrm{~mm} \\
\text { stainless } \\
\text { steel ball } \\
\end{array}$ \\
\hline & In-Ceram & $\begin{array}{c}\text { Porcelain (Vita } \\
\text { Alpha, Dentine } \\
\text { porcelain) }\end{array}$ & posterior & $1901 \pm 303$ & 1.000 & $20-300$ & n.a. & n.a. & $1422 \pm 112$ & $\begin{array}{c}4 \mathrm{~mm} \\
\text { stainless } \\
\text { steel ball }\end{array}$ \\
\hline & IPS & & posterior & $1751 \pm 194$ & 1.000 & $20-300$ & n.a. & n.a. & $1586 \pm 116$ & $\begin{array}{c}4 \mathrm{~mm} \\
\text { stainless } \\
\text { steel ball }\end{array}$ \\
\hline & IPS & & posterior & $1751 \pm 194$ & 1.000 & $20-300$ & n.a. & n.a. & $1467 \pm 162$ & $\begin{array}{c}4 \mathrm{~mm} \\
\text { stainless } \\
\text { steel ball }\end{array}$ \\
\hline & OPC & & posterior & $1583 \pm 115$ & 1.000 & $20-300$ & n.a. & n.a. & $1374 \pm 201$ & $\begin{array}{c}4 \mathrm{~mm} \\
\text { stainless } \\
\text { steel ball }\end{array}$ \\
\hline & OPC & & posterior & $1583 \pm 115$ & 1.000 & $20-300$ & n.a. & n.a. & $1285 \pm 200$ & $\begin{array}{c}4 \mathrm{~mm} \\
\text { stainless } \\
\text { steel ball }\end{array}$ \\
\hline
\end{tabular}

Table 1a. Fracture strength of crowns made of different all-ceramic materials with and without cyclic loading together with cyclic loading test parameters. 


\begin{tabular}{|c|c|c|c|c|c|c|c|c|c|c|}
\hline Author & $\begin{array}{c}\text { Framework } \\
\text { ceramic }\end{array}$ & $\begin{array}{l}\text { Veneering } \\
\text { ceramic }\end{array}$ & Location & \begin{tabular}{|c|}
$\begin{array}{c}\text { Fracture } \\
\text { strength }(\mathrm{N}) \\
\text { before } \\
\text { fatigue }\end{array}$ \\
\end{tabular} & $\begin{array}{c}\text { Fatigue } \\
\text { conditions }\end{array}$ & & & & $\begin{array}{c}\text { Fracture } \\
\text { strength }(\mathrm{N}) \\
\text { after fatigue }\end{array}$ & \\
\hline & & & & & $\begin{array}{c}\text { Number of } \\
\text { Cycles }\end{array}$ & $\begin{array}{c}\text { Force } \\
\text { (N) }\end{array}$ & Temperature & Indenter & & Indenter \\
\hline $\begin{array}{c}\text { Eroğlu Z and } \\
\text { Gurbulak AG. }{ }^{24}\end{array}$ & \begin{tabular}{|c|} 
Zirconia \\
(Copran \\
zircon \\
blanks; \\
White Peaks \\
Dental \\
Systems \\
GmbH \& Co, \\
Essen, \\
Germany \\
\end{tabular} & Ceramics & posterior & $2434 \pm 154.34$ & 0.1 & 50 & $5-55^{\circ} \mathrm{C}$ & n.a. & $2333.1 \pm 183.02$ & $\begin{array}{c}3 \mathrm{~mm} \\
\text { steel ball }\end{array}$ \\
\hline $\begin{array}{c}\text { Chitmongkolsuk } \\
\mathrm{S} \text { et al. }{ }^{18}\end{array}$ & $\begin{array}{c}\text { IPS Empress } \\
\text { 2, Ivoclar) }\end{array}$ & \begin{tabular}{|c}
$\begin{array}{c}\text { Porcelain } \\
\text { (IPS }\end{array}$ \\
Empress \\
2, Ivoclar) \\
\end{tabular} & posterior & 1300 & $1.2 \times 10^{6}$ & 49 & $5-55^{\circ} \mathrm{C}$ & $\begin{array}{c}6 \mathrm{~mm} \\
\begin{array}{c}\text { ceramic } \\
\text { ball }\end{array}\end{array}$ & 923.8 & n.a. \\
\hline & $\begin{array}{c}\text { IPS Empress } \\
\text { 2, Ivoclar) }\end{array}$ & \begin{tabular}{|l|}
$\begin{array}{c}\text { Porcelain } \\
\text { (IPS } \\
\text { Empress } \\
2 \text {, Ivoclar) }\end{array}$ \\
\end{tabular} & posterior & 1273 & $1.2 \times 10^{6}$ & 49 & $5-55^{\circ} \mathrm{C}$ & $\begin{array}{c}6 \mathrm{~mm} \\
\text { ceramic } \\
\text { ball }\end{array}$ & 1161 & n.a. \\
\hline \multirow[t]{2}{*}{$\begin{array}{c}\text { Kohorst } \mathrm{P} \text { et } \\
\text { al. }^{32}\end{array}$} & $\begin{array}{c}\text { Zirconia } \\
\text { dioxide } \\
\text { (Cercon } \\
\text { base, } \\
\text { DeguDent, } \\
\text { Hanau, } \\
\text { Germany) }\end{array}$ & & posterior & $1525 \pm 76.5$ & $1 \times 10^{6}$ & $\begin{array}{c}\max \\
100 \\
\end{array}$ & $5-55^{\circ} \mathrm{C}$ & n.a. & $903.7 \pm 40.8$ & $\begin{array}{c}6 \mathrm{~mm} \\
\text { WC ball }\end{array}$ \\
\hline & $\begin{array}{c}\text { Zirconia } \\
\text { dioxide } \\
\text { (Cercon } \\
\text { base, } \\
\text { DeguDent, } \\
\text { Hanau, } \\
\text { Germany) }\end{array}$ & & posterior & $1525 \pm 76.5$ & $2 \times 10^{6}$ & $\begin{array}{l}\max \\
100\end{array}$ & $5-55^{\circ} \mathrm{C}$ & n.a. & $923.5 \pm 40.3$ & $\begin{array}{c}6 \mathrm{~mm} \\
\text { WC ball }\end{array}$ \\
\hline
\end{tabular}




\begin{tabular}{|c|c|c|c|c|c|c|c|c|c|c|}
\hline & $\begin{array}{c}\text { Zirconia } \\
\text { dioxide } \\
\text { (Cercon } \\
\text { base, } \\
\text { DeguDent, } \\
\text { Hanau, } \\
\text { Germany) }\end{array}$ & & posterior & $1525 \pm 76.5$ & $1 \times 10^{6}$ & $\begin{array}{l}\max \\
200\end{array}$ & $5-55^{\circ} \mathrm{C}$ & n.a. & $952.4 \pm 51.4$ & $\begin{array}{c}6 \mathrm{~mm} \text { WC } \\
\text { ball }\end{array}$ \\
\hline \multirow[t]{3}{*}{ Beuer F et al. ${ }^{11}$} & $\begin{array}{l}\text { Sintered } \\
\text { alumina } \\
\text { (InCeram } \\
\text { Alumina) }\end{array}$ & $\begin{array}{l}\text { Porcelain } \\
\text { (VM7 Vita) }\end{array}$ & posterior & $851+-331$ & $1.2 \times 10^{6}$ & 50 & $5-55^{\circ} \mathrm{C}$ & $\begin{array}{c}6 \mathrm{~mm} \\
\text { WC ball }\end{array}$ & $659 \pm 182$ & $\begin{array}{l}10 \mathrm{~mm} \\
\text { WC ball }\end{array}$ \\
\hline & $\begin{array}{c}\text { Sintered } \\
\text { alumina } \\
\text { reinforced } \\
\text { with zirconia } \\
\text { (InCeram } \\
\text { Zirconia) } \\
\end{array}$ & $\begin{array}{l}\text { Porcelain } \\
\text { (VM7 Vita) }\end{array}$ & posterior & $841+-244$ & $1.2 \times 10^{6}$ & 50 & $5-55^{\circ} \mathrm{C}$ & $\begin{array}{c}6 \mathrm{~mm} \\
\text { WC ball }\end{array}$ & $770 \pm 186$ & $\begin{array}{l}10 \mathrm{~mm} \\
\mathrm{WC} \text { ball }\end{array}$ \\
\hline & $\begin{array}{c}\text { Semi } \\
\text { sintered } \\
\text { zirconia } \\
\text { (InCeram } \\
\text { YZ) } \\
\end{array}$ & $\begin{array}{l}\text { Porcelain } \\
\text { (VM7 Vita) }\end{array}$ & posterior & $981+-266$ & $1.2 \times 10^{6}$ & 50 & $5-55^{\circ} \mathrm{C}$ & $\begin{array}{c}6 \mathrm{~mm} \\
\text { WC ball }\end{array}$ & $1042 \pm 195$ & $\begin{array}{l}10 \mathrm{~mm} \\
\mathrm{WC} \text { ball }\end{array}$ \\
\hline $\begin{array}{c}\text { Schultheis S et } \\
\text { al. }^{58}\end{array}$ & $\begin{array}{l}\text { IPS e.max } \\
\text { CAD, Ivoclar, } \\
\text { Vivadent, } \\
\text { Schaan, } \\
\text { Liechtenstein }\end{array}$ & $\begin{array}{l}\text { IPS e.max } \\
\text { Ceram } \\
\text { (Ivoclar, } \\
\text { Vivadent) }\end{array}$ & posterior & 1298 & $1.2 \times 10^{6}$ & 49 & $5-55^{\circ} \mathrm{C}$ & $\begin{array}{c}3 \mathrm{~mm} \\
\text { ceramic } \\
\text { ball }\end{array}$ & 1900 & $\begin{array}{l}3.18 \mathrm{~mm} \\
\text { steel ball }\end{array}$ \\
\hline
\end{tabular}

Table 1b. Fracture strength of 3-unit FDPs made of different all-ceramic materials with and without cyclic loading together with cyclic loading test parameters. 


\begin{tabular}{|c|c|c|c|c|}
\hline & Author & Title & Publication & Exclusion Criteria \\
\hline 1 & $\begin{array}{l}\text { Aboushelib } \\
\text { MN. }^{1}\end{array}$ & $\begin{array}{l}\text { Fatigue and fracture resistance of } \\
\text { zirconia crowns prepared with } \\
\text { different finish line designs. }\end{array}$ & $\begin{array}{l}\text { J Prosthodont } \\
\text { 2012;21:22-27. }\end{array}$ & $\begin{array}{l}\text { No initial fracture } \\
\text { load, force } \\
\text { presented in kg, } \\
\text { indender-shape not } \\
\text { defined. Surface } \\
\text { area is missing. }\end{array}$ \\
\hline 2 & $\begin{array}{l}\text { Aboushelib } \\
\mathrm{MN}^{2}\end{array}$ & $\begin{array}{l}\text { Simulation of cumulative damage } \\
\text { associated with long term cyclic } \\
\text { loading using a multi-level strain } \\
\text { accommodating loading protocol. }\end{array}$ & $\begin{array}{l}\text { Dent Mater } \\
\text { 2013;29:252-258. }\end{array}$ & $\begin{array}{l}\text { No initial and final } \\
\text { fracture load, force } \\
\text { presented in } \mathrm{N} \text { and } \\
\mathrm{kg} \text {. }\end{array}$ \\
\hline 3 & $\begin{array}{l}\text { Alhasanyah } \mathrm{A}, \\
\text { Vaidyanathan } \\
\text { TK, Flinton } \\
\text { RJ. }^{3}\end{array}$ & $\begin{array}{l}\text { Effect of core thickness } \\
\text { differences on post-fatigue } \\
\text { indentation fracture resistance of } \\
\text { veneered zirconia crowns. }\end{array}$ & $\begin{array}{l}\text { J Prosthodont } \\
\text { 2013;22:383-390. }\end{array}$ & $\begin{array}{l}\text { No initial fracture } \\
\text { load. }\end{array}$ \\
\hline 4 & $\begin{array}{l}\text { Attia A, } \\
\text { Abdelaziz KM, } \\
\text { Freitag S, Kern } \\
\text { M. }^{4}\end{array}$ & $\begin{array}{l}\text { Fracture load of composite resin } \\
\text { and feldspathic all-ceramic } \\
\text { CAD/CAM crowns. }\end{array}$ & $\begin{array}{l}\text { J Prosthet Dent } \\
\text { 2006;95:117-123. }\end{array}$ & $\begin{array}{l}\text { Monolithic } \\
\text { restorations. }\end{array}$ \\
\hline 5 & $\begin{array}{l}\text { Azer SS, } \\
\text { Drummond JL, } \\
\text { Campbell SD, } \\
\text { El Moneim } \\
\text { Zaki A. }^{6}\end{array}$ & $\begin{array}{l}\text { Influence of core buildup material } \\
\text { on the fatigue strength of an all- } \\
\text { ceramic crown. }\end{array}$ & $\begin{array}{l}\text { J Prosthet Dent } \\
2001 ; 86: 624-631 .\end{array}$ & $\begin{array}{l}\text { No final fracture } \\
\text { load. }\end{array}$ \\
\hline 6 & $\begin{array}{l}\text { Behr M, } \\
\text { Rosentritt M, } \\
\text { Mangelkramer } \\
\text { M, Handel G. }\end{array}$ & $\begin{array}{l}\text { The influence of different cements } \\
\text { on the fracture resistance and } \\
\text { marginal adaptation of all-ceramic } \\
\text { and fiber-reinforced crowns. }\end{array}$ & $\begin{array}{l}\text { Int J Prosthodont } \\
2003 ; 16: 538-542 .\end{array}$ & $\begin{array}{l}\text { No initial fracture } \\
\text { load. }\end{array}$ \\
\hline 7 & $\begin{array}{l}\text { Belli R, } \\
\text { Frankenberger } \\
\text { R, Appelt A, } \\
\text { Schmitt J, } \\
\text { Baratieri LN, } \\
\text { Greil P, } \\
\text { Lohbauer U. }{ }^{9}\end{array}$ & $\begin{array}{l}\text { Thermal-induced residual } \\
\text { stresses affect the lifetime of } \\
\text { zirconia-veneer crowns. }\end{array}$ & $\begin{array}{l}\text { Dent Mater } \\
\text { 2013;29:181-190. }\end{array}$ & $\begin{array}{l}\text { No final fracture } \\
\text { load. }\end{array}$ \\
\hline 8 & \begin{tabular}{|l} 
Belli R, \\
Petschelt A,
\end{tabular} & $\begin{array}{l}\text { Thermal-induced residual } \\
\text { stresses affect the fractographic }\end{array}$ & $\begin{array}{l}\text { J Mech Behav } \\
\text { Biomed Mater }\end{array}$ & $\begin{array}{l}\text { No final and initial } \\
\text { fracture load. }\end{array}$ \\
\hline
\end{tabular}




\begin{tabular}{|c|c|c|c|c|}
\hline & Lohbauer U. ${ }^{10}$ & $\begin{array}{l}\text { patterns of zirconia-veneer dental } \\
\text { prostheses. }\end{array}$ & 2013;21:167-177. & \\
\hline 9 & $\begin{array}{l}\text { Beuer F, } \\
\text { Stimmelmayr } \\
\text { M, Gueth JF, } \\
\text { Edelhoff D, } \\
\text { Naumann M. }{ }^{12}\end{array}$ & $\begin{array}{l}\text { In vitro performance of full- } \\
\text { contour zirconia single crowns. }\end{array}$ & $\begin{array}{l}\text { Dent Mater } \\
\text { 2012;28:449-456. }\end{array}$ & $\begin{array}{l}\text { No initial fracture } \\
\text { load. }\end{array}$ \\
\hline 10 & $\begin{array}{l}\text { Blatz MB, } \\
\text { Oppes S, } \\
\text { Chiche G, } \\
\text { Holst S, Sadan } \\
\text { A. }{ }^{13}\end{array}$ & $\begin{array}{l}\text { Influence of cementation } \\
\text { technique on fracture strength } \\
\text { and leakage of alumina all- } \\
\text { ceramic crowns after cyclic } \\
\text { loading. }\end{array}$ & $\begin{array}{l}\text { Quintessence Int } \\
\text { 2008;39:23-32. }\end{array}$ & $\begin{array}{l}\text { No initial fracture } \\
\text { load. }\end{array}$ \\
\hline 11 & $\begin{array}{l}\text { Bonfante EA, } \\
\text { Rafferty B, } \\
\text { Zavanelli RA, } \\
\text { Silva NR, } \\
\text { Rekow ED, } \\
\text { Thompson VP, } \\
\text { Coelho PG. }{ }^{14}\end{array}$ & $\begin{array}{l}\text { Thermal/mechanical simulation } \\
\text { and laboratory fatigue testing of } \\
\text { an alternative yttria tetragonal } \\
\text { zirconia polycrystal core-veneer } \\
\text { all-ceramic layered crown design. }\end{array}$ & $\begin{array}{l}\text { Eur J Oral Sci } \\
\text { 2010;118:202-209. }\end{array}$ & $\begin{array}{l}\text { No final fracture } \\
\text { load. }\end{array}$ \\
\hline 12 & $\begin{array}{l}\text { Bonfante EA, } \\
\text { Sailer I, Silva } \\
\text { NR, Thompson } \\
\text { VP, Dianne } \\
\text { Rekow E, } \\
\text { Coelho PG. }{ }^{15}\end{array}$ & $\begin{array}{l}\text { Failure modes of Y-TZP crowns } \\
\text { at different cusp inclines. }\end{array}$ & $\begin{array}{l}\text { J Dent } \\
\text { 2010;38:707-712. }\end{array}$ & $\begin{array}{l}\text { No initial and final } \\
\text { fracture load. }\end{array}$ \\
\hline 13 & $\begin{array}{l}\text { Chen HY, } \\
\text { Hickel R, } \\
\text { Setcos JC, } \\
\text { Kunzelmann } \\
\mathrm{KH}^{17}\end{array}$ & $\begin{array}{l}\text { Effects of surface finish and } \\
\text { fatigue testing on the fracture } \\
\text { strength of CAD-CAM and } \\
\text { pressed-ceramic crowns. }\end{array}$ & $\begin{array}{l}\text { J Prosthet Dent } \\
\text { 1999;82:468-475. }\end{array}$ & $\begin{array}{l}\text { Monolithic } \\
\text { restorations. }\end{array}$ \\
\hline 14 & $\begin{array}{l}\text { Coelho PG, } \\
\text { Bonfante EA, } \\
\text { Silva NR, } \\
\text { Rekow ED, } \\
\text { Thompson } \\
\text { VP. }^{19}\end{array}$ & $\begin{array}{l}\text { Laboratory simulation of Y-TZP } \\
\text { all-ceramic crown clinical failures. }\end{array}$ & $\begin{array}{l}\text { J Dent Res } \\
\text { 2009;88:382-386. }\end{array}$ & $\begin{array}{l}\text { No final fracture } \\
\text { load. }\end{array}$ \\
\hline
\end{tabular}




\begin{tabular}{|c|c|c|c|c|}
\hline 15 & $\begin{array}{l}\text { Coelho PG, } \\
\text { Silva NR, } \\
\text { Bonfante EA, } \\
\text { Guess PC, } \\
\text { Rekow ED, } \\
\text { Thompson } \\
\text { VP. }{ }^{20}\end{array}$ & $\begin{array}{l}\text { Fatigue testing of two porcelain- } \\
\text { zirconia all-ceramic crown } \\
\text { systems. }\end{array}$ & $\begin{array}{l}\text { Dent Mater } \\
2009 ; 25: 1122- \\
1127 .\end{array}$ & $\begin{array}{l}\text { No final fracture } \\
\text { load. }\end{array}$ \\
\hline 16 & $\begin{array}{l}\text { Corazza PH, } \\
\text { Feitosa SA, } \\
\text { Borges AL, } \\
\text { Della Bona A. }{ }^{22}\end{array}$ & $\begin{array}{l}\text { Influence of convergence angle of } \\
\text { tooth preparation on the fracture } \\
\text { resistance of Y-TZP-based all- } \\
\text { ceramic restorations. }\end{array}$ & $\begin{array}{l}\text { Dent Mater } \\
\text { 2013;29:339-347. }\end{array}$ & $\begin{array}{l}\text { Restorations not } \\
\text { anatomic. }\end{array}$ \\
\hline 17 & $\begin{array}{l}\text { Gresnigt MM, } \\
\text { Ozcan M, Kalk } \\
\text { W, Galhano } \\
\text { G. }{ }^{25}\end{array}$ & $\begin{array}{l}\text { Effect of static and cyclic loading } \\
\text { on ceramic laminate veneers } \\
\text { adhered to teeth with and without } \\
\text { aged composite restorations. }\end{array}$ & $\begin{array}{l}\text { J Adhes Dent } \\
\text { 2011;13:569-577. }\end{array}$ & $\begin{array}{l}\text { No final fracture } \\
\text { load. }\end{array}$ \\
\hline 18 & $\begin{array}{l}\text { Guess PC, } \\
\text { Bonfante EA, } \\
\text { Silva NR, } \\
\text { Coelho PG, } \\
\text { Thompson } \\
\text { VP. }{ }^{26}\end{array}$ & $\begin{array}{l}\text { Effect of core design and } \\
\text { veneering technique on damage } \\
\text { and reliability of Y-TZP-supported } \\
\text { crowns. }\end{array}$ & $\begin{array}{l}\text { Dent Mater } \\
\text { 2013;29:307-316. }\end{array}$ & $\begin{array}{l}\text { No final fracture } \\
\text { load. }\end{array}$ \\
\hline 19 & $\begin{array}{l}\text { Guess PC, } \\
\text { Zavanelli RA, } \\
\text { Silva NR, } \\
\text { Bonfante EA, } \\
\text { Coelho PG, } \\
\text { Thompson } \\
\text { VP. }{ }^{27}\end{array}$ & $\begin{array}{l}\text { Monolithic CAD/CAM lithium } \\
\text { disilicate versus veneered Y-TZP } \\
\text { crowns: comparison of failure } \\
\text { modes and reliability after fatigue. }\end{array}$ & $\begin{array}{l}\text { Int J Prosthodont. } \\
\text { 2010;23:434-442. }\end{array}$ & $\begin{array}{l}\text { No final fracture } \\
\text { load. ( }\end{array}$ \\
\hline 20 & $\begin{array}{l}\text { Kassem AS, } \\
\text { Atta O, El- } \\
\text { Mowafy } \text { O. }^{29}\end{array}$ & $\begin{array}{l}\text { Combined effects of } \\
\text { thermocycling and load-cycling on } \\
\text { microleakage of computer-aided } \\
\text { design/computer-assisted } \\
\text { manufacture molar crowns. }\end{array}$ & $\begin{array}{l}\text { Int J Prosthodont } \\
2011 ; 24: 376-378 .\end{array}$ & $\begin{array}{l}\text { Monolithic } \\
\text { restoration only. No } \\
\text { initial and final } \\
\text { fracture load. }\end{array}$ \\
\hline 21 & $\begin{array}{l}\text { Kassem AS, } \\
\text { Atta O, El- } \\
\text { Mowafy O. }\end{array}$ & $\begin{array}{l}\text { Fatigue resistance and } \\
\text { microleakage of CAD/CAM } \\
\text { ceramic and composite molar }\end{array}$ & $\begin{array}{l}\text { J Prosthodont } \\
\text { 2012;21:28-32. }\end{array}$ & $\begin{array}{l}\text { No initial and final } \\
\text { fracture load. }\end{array}$ \\
\hline
\end{tabular}




\begin{tabular}{|c|c|c|c|c|}
\hline & & crowns. & & \\
\hline 22 & $\begin{array}{l}\text { Kheradmandan } \\
\text { S, Koutayas } \\
\text { SO, Bernhard } \\
\text { M, Strub JR. }{ }^{32}\end{array}$ & $\begin{array}{l}\text { Fracture strength of four different } \\
\text { types of anterior 3-unit bridges } \\
\text { after thermo-mechanical fatigue } \\
\text { in the dual-axis chewing } \\
\text { simulator. }\end{array}$ & $\begin{array}{l}\text { J Oral Rehabil } \\
2001 ; 28: 361-369 .\end{array}$ & $\begin{array}{l}\text { No initial fracture } \\
\text { load. }\end{array}$ \\
\hline 23 & $\begin{array}{l}\text { Kolbeck C, } \\
\text { Rosentritt M, } \\
\text { Handel G. }\end{array}$ & $\begin{array}{l}\text { Fracture strength of artificially } \\
\text { aged 3-unit adhesive fixed partial } \\
\text { dentures made of fiber-reinforced } \\
\text { composites and ceramics: an in } \\
\text { vitro study. }\end{array}$ & $\begin{array}{l}\text { Quintessence Int } \\
2006 ; 37: 731-735 .\end{array}$ & $\begin{array}{l}\text { No initial fracture } \\
\text { load. }\end{array}$ \\
\hline 24 & $\begin{array}{l}\text { Larsson C, } \\
\text { Holm L, } \\
\text { Lovgren N, } \\
\text { Kokubo Y, Vult } \\
\text { von Steyern } \\
\text { P. }{ }^{37}\end{array}$ & $\begin{array}{l}\text { Fracture strength of four-unit Y- } \\
\text { TZP FPD cores designed with } \\
\text { varying connector diameter. An } \\
\text { in-vitro study. }\end{array}$ & $\begin{array}{l}\text { J Oral Rehabil } \\
2007 ; 34: 702-709 .\end{array}$ & $\begin{array}{l}\text { No initial fracture } \\
\text { load. }\end{array}$ \\
\hline 25 & $\begin{array}{l}\text { Lorenzoni FC, } \\
\text { Martins LM, } \\
\text { Silva NR, } \\
\text { Coelho PG, } \\
\text { Guess PC, } \\
\text { Bonfante EA, } \\
\text { Thompson VP, } \\
\text { Bonfante G. }{ }^{39}\end{array}$ & $\begin{array}{l}\text { Fatigue life and failure modes of } \\
\text { crowns systems with a modified } \\
\text { framework design. }\end{array}$ & $\begin{array}{l} \\
\text { J Dent } \\
2010 ; 38: 626-634 .\end{array}$ & $\begin{array}{l}\text { No final fracture } \\
\text { load. }\end{array}$ \\
\hline 26 & $\begin{array}{l}\text { Mörmann W, } \\
\text { Wolf D, Ender } \\
\text { A, Bindl A, } \\
\text { Göhring T, } \\
\text { Attin T. }{ }^{40}\end{array}$ & $\begin{array}{l}\text { Effect of two self-adhesive } \\
\text { cements on marginal adaptation } \\
\text { and strength of esthetic ceramic } \\
\text { CAD/CAM molar crowns. }\end{array}$ & $\begin{array}{l}\text { J Prosthodont } \\
2009 ; 18: 403-410 .\end{array}$ & $\begin{array}{l}\text { No final fracture } \\
\text { load. }\end{array}$ \\
\hline 27 & $\begin{array}{l}\text { Mahmood DJ, } \\
\text { Linderoth EH, } \\
\text { Vult Von } \\
\text { Steyern P. }{ }^{41}\end{array}$ & $\begin{array}{l}\text { The influence of support } \\
\text { properties and complexity on } \\
\text { fracture strength and fracture } \\
\text { mode of all-ceramic fixed dental } \\
\text { prostheses. }\end{array}$ & $\begin{array}{l}\text { Acta Odontol } \\
\text { Scand } \\
2011 ; 69: 229-237 .\end{array}$ & $\begin{array}{l}\text { No initial fracture } \\
\text { load. }\end{array}$ \\
\hline
\end{tabular}




\begin{tabular}{|c|c|c|c|c|}
\hline 28 & $\begin{array}{l}\text { Ohlmann B, } \\
\text { Dittmar A, } \\
\text { Rues S, } \\
\text { Rammelsberg } \\
\text { P. }{ }^{2}\end{array}$ & $\begin{array}{l}\text { Comparison of fracture-load } \\
\text { values of cantilevered FDPs. }\end{array}$ & $\begin{array}{l}\text { Acta Odontol } \\
\text { Scand } \\
2013 ; 71: 584-589 .\end{array}$ & $\begin{array}{l}\text { No initial fracture } \\
\text { load. }\end{array}$ \\
\hline 29 & $\begin{array}{l}\text { Okutan M, } \\
\text { Heydecke G, } \\
\text { Butz F, Strub } \\
\text { JR. }{ }^{43}\end{array}$ & $\begin{array}{l}\text { Fracture load and marginal fit of } \\
\text { shrinkage-free } \mathrm{ZrSiO} 4 \text { all-ceramic } \\
\text { crowns after chewing simulation. }\end{array}$ & $\begin{array}{l}\text { J Oral Rehabil } \\
\text { 2006;33:827-832. }\end{array}$ & $\begin{array}{l}\text { No initial fracture } \\
\text { load. }\end{array}$ \\
\hline 30 & $\begin{array}{l}\text { Preis V, Behr } \\
\text { M, Hahnel S, } \\
\text { Handel G, } \\
\text { Rosentritt M. }{ }^{45}\end{array}$ & $\begin{array}{l}\text { In vitro failure and fracture } \\
\text { resistance of veneered and full- } \\
\text { contour zirconia restorations. }\end{array}$ & $\begin{array}{l}\text { J Dent } \\
\text { 2012;40:921-928. }\end{array}$ & $\begin{array}{l}\text { No initial fracture } \\
\text { load. }\end{array}$ \\
\hline 31 & $\begin{array}{l}\text { Preis V, Letsch } \\
\text { C, Handel G, } \\
\text { Behr M, } \\
\text { Schneider- } \\
\text { Feyrer S, } \\
\text { Rosentritt M. }\end{array}$ & $\begin{array}{l}\text { Influence of substructure design, } \\
\text { veneer application technique, and } \\
\text { firing regime on the in vitro } \\
\text { performance of molar zirconia } \\
\text { crowns. }\end{array}$ & $\begin{array}{l}\text { Dent Mater } \\
\text { 2013;29:e113-21. }\end{array}$ & $\begin{array}{l}\text { No initial fracture } \\
\text { load. }\end{array}$ \\
\hline 32 & $\begin{array}{l}\text { Rekow ED, } \\
\text { Zhang G, } \\
\text { Thompson V, } \\
\text { Kim JW, } \\
\text { Coehlo P, } \\
\text { Zhang Y. }{ }^{47}\end{array}$ & $\begin{array}{l}\text { Effects of geometry on fracture } \\
\text { initiation and propagation in all- } \\
\text { ceramic crowns. }\end{array}$ & $\begin{array}{l}\text { J Biomed Mater } \\
\text { Res B Appl } \\
\text { Biomater } \\
\text { 2009;88:436-446. }\end{array}$ & $\begin{array}{l}\text { No initial and final } \\
\text { fracture load. }\end{array}$ \\
\hline 33 & $\begin{array}{l}\text { Rosentritt M, } \\
\text { Behr M, } \\
\text { Gebhard R, } \\
\text { Handel G. }{ }^{49}\end{array}$ & $\begin{array}{l}\text { Influence of stress simulation } \\
\text { parameters on the fracture } \\
\text { strength of all-ceramic fixed- } \\
\text { partial dentures. }\end{array}$ & $\begin{array}{l}\text { Dent Mater } \\
2006 ; 22: 176-182 .\end{array}$ & $\begin{array}{l}\text { No initial fracture } \\
\text { load. }\end{array}$ \\
\hline 34 & $\begin{array}{l}\text { Rosentritt M, } \\
\text { Behr M, } \\
\text { Scharnagl P, } \\
\text { Handel G, } \\
\text { Kolbeck C. }\end{array}$ & $\begin{array}{l}\text { Influence of resilient support of } \\
\text { abutment teeth on fracture } \\
\text { resistance of all-ceramic fixed } \\
\text { partial dentures: an in vitro study. }\end{array}$ & $\begin{array}{l}\text { Int J Prosthodont } \\
2011 ; 24: 465-468 .\end{array}$ & $\begin{array}{l}\text { No initial fracture } \\
\text { load. }\end{array}$ \\
\hline & $\begin{array}{l}\text { Rosentritt M, } \\
\text { Kolbeck C, }\end{array}$ & $\begin{array}{l}\text { Influence of the fabrication } \\
\text { process on the in vitro }\end{array}$ & $\begin{array}{l}\text { Clin Oral Investig } \\
2011 ; 15: 1007-\end{array}$ & $\begin{array}{l}\text { No initial fracture } \\
\text { load. }\end{array}$ \\
\hline
\end{tabular}




\begin{tabular}{|c|c|c|c|c|}
\hline 35 & $\begin{array}{l}\text { Handel G, } \\
\text { Schneider- } \\
\text { Feyrer S, Behr } \\
\text { M. }{ }^{51}\end{array}$ & $\begin{array}{l}\text { performance of fixed dental } \\
\text { prostheses with zirconia } \\
\text { substructures. }\end{array}$ & 1012. & \\
\hline 36 & $\begin{array}{l}\text { Rosentritt M, } \\
\text { Plein T, } \\
\text { Kolbeck C, } \\
\text { Behr M, } \\
\text { Handel G. }^{52}\end{array}$ & $\begin{array}{l}\text { In vitro fracture force and } \\
\text { marginal adaptation of ceramic } \\
\text { crowns fixed on natural and } \\
\text { artificial teeth. }\end{array}$ & $\begin{array}{l}\text { Int J Prosthodont } \\
\text { 2000;13:387-391. }\end{array}$ & $\begin{array}{l}\text { No initial fracture } \\
\text { load. }\end{array}$ \\
\hline 37 & $\begin{array}{l}\text { Rosentritt M, } \\
\text { Siavikis G, } \\
\text { Behr M, } \\
\text { Kolbeck C, } \\
\text { Handel G. }^{53}\end{array}$ & $\begin{array}{l}\text { Approach for valuating the } \\
\text { significance of laboratory } \\
\text { simulation. }\end{array}$ & $\begin{array}{l}\text { J Dent } \\
2008 ; 36: 1048- \\
1053 .\end{array}$ & $\begin{array}{l}\text { No initial fracture } \\
\text { load. }\end{array}$ \\
\hline 38 & $\begin{array}{l}\text { Rosentritt M, } \\
\text { Steiger D, Behr } \\
\text { M, Handel G, } \\
\text { Kolbeck C. }{ }^{54}\end{array}$ & $\begin{array}{l}\text { Influence of substructure design } \\
\text { and spacer settings on the in vitro } \\
\text { performance of molar zirconia } \\
\text { crowns. }\end{array}$ & $\begin{array}{l}\text { J Dent } \\
\text { 2009;37:978-983. }\end{array}$ & $\begin{array}{l}\text { No initial and final } \\
\text { fracture load. }\end{array}$ \\
\hline 39 & $\begin{array}{l}\text { Senyilmaz DP, } \\
\text { Canay S, } \\
\text { Heydecke G, } \\
\text { Strub JR. }{ }^{58}\end{array}$ & $\begin{array}{l}\text { Influence of thermomechanical } \\
\text { fatigue loading on the fracture } \\
\text { resistance of all-ceramic posterior } \\
\text { crowns. }\end{array}$ & $\begin{array}{l}\text { Eur J Prosthodont } \\
\text { Restor Dent } \\
\text { 2010;18:50-54. }\end{array}$ & $\begin{array}{l}\text { No initial and final } \\
\text { fracture load. }\end{array}$ \\
\hline 40 & $\begin{array}{l}\text { Silva NR, } \\
\text { Bonfante E, } \\
\text { Rafferty BT, } \\
\text { Zavanelli RA, } \\
\text { Martins LL, } \\
\text { Rekow ED, } \\
\text { Thompson VP, } \\
\text { Coehlo PG. }{ }^{60}\end{array}$ & $\begin{array}{l}\text { Conventional and modified } \\
\text { veneered zirconia vs. } \\
\text { metalloceramic: fatigue and finite } \\
\text { element analysis. }\end{array}$ & $\begin{array}{l}\text { J Prosthodont } \\
2012 ; 21: 433-439 .\end{array}$ & $\begin{array}{l}\text { No final fracture } \\
\text { load. }\end{array}$ \\
\hline 41 & $\begin{array}{l}\text { Silva NR, } \\
\text { Bonfante EA, } \\
\text { Rafferty BT, } \\
\text { Zavanelli RA, } \\
\text { Rekow ED, } \\
\text { Thompson VP, }\end{array}$ & $\begin{array}{l}\text { Modified Y-TZP core design } \\
\text { improves all-ceramic crown } \\
\text { reliability. }\end{array}$ & $\begin{array}{l}\text { J Dent Res } \\
\text { 2011;90:104-108. }\end{array}$ & $\begin{array}{l}\text { No final fracture } \\
\text { load. }\end{array}$ \\
\hline
\end{tabular}




\begin{tabular}{|c|c|c|c|c|}
\hline & Coelho PG. ${ }^{61}$ & & & \\
\hline 42 & $\begin{array}{l}\text { Silva NR, } \\
\text { Bonfante EA, } \\
\text { Zavanelli RA, } \\
\text { Thompson VP, } \\
\text { Ferencz JL, } \\
\text { Coelho PG. }{ }^{62}\end{array}$ & $\begin{array}{l}\text { Reliability of metalloceramic and } \\
\text { zirconia-based ceramic crowns. }\end{array}$ & $\begin{array}{l}\text { J Dent Res } \\
2010 ; 89: 1051- \\
1056 .\end{array}$ & $\begin{array}{l}\text { No final fracture } \\
\text { load. }\end{array}$ \\
\hline 43 & $\begin{array}{l}\text { Silva NR, } \\
\text { Thompson VP, } \\
\text { Valverde GB, } \\
\text { Coelho PG, } \\
\text { Powers JM, } \\
\text { Farah JW, } \\
\text { Esquivel- } \\
\text { Upshaw J. }\end{array}$ & $\begin{array}{l}\text { Comparative reliability analyses } \\
\text { of zirconium oxide and lithium } \\
\text { disilicate restorations in vitro and } \\
\text { in vivo. }\end{array}$ & $\begin{array}{l}\text { J Am Dent Assoc } \\
2011 ; 142: 4 S-9 S .\end{array}$ & $\begin{array}{l}\text { No final fracture } \\
\text { load. }\end{array}$ \\
\hline 44 & $\begin{array}{l}\text { Skouridou N, } \\
\text { Pollington S, } \\
\text { Rosentritt M, } \\
\text { Tsitrou E. }^{64}\end{array}$ & $\begin{array}{l}\text { Fracture strength of minimally } \\
\text { prepared all-ceramic CEREC } \\
\text { crowns after simulating } 5 \text { years of } \\
\text { service. }\end{array}$ & $\begin{array}{l}\text { Dent Mater } \\
\text { 2013;29:e70-7. }\end{array}$ & $\begin{array}{l}\text { No initial fracture } \\
\text { load. }\end{array}$ \\
\hline 45 & $\begin{array}{l}\text { Slavcheva S, } \\
\text { Krejci I, } \\
\text { Bortolotto T. }{ }^{65}\end{array}$ & $\begin{array}{l}\text { Luting of ceramic crowns with a } \\
\text { self-adhesive cement: effect of } \\
\text { contamination on marginal } \\
\text { adaptation and fracture strength. }\end{array}$ & $\begin{array}{l}\text { Med Oral Patol } \\
\text { Oral Cir Bucal } \\
\text { 2013;18:e799-803. }\end{array}$ & $\begin{array}{l}\text { No initial fracture } \\
\text { load. }\end{array}$ \\
\hline 46 & $\begin{array}{l}\text { Sundh A, Molin } \\
\text { M, Sjögren } \\
\text { G. }^{68}\end{array}$ & $\begin{array}{l}\text { Fracture resistance of yttrium } \\
\text { oxide partially-stabilized zirconia } \\
\text { all-ceramic bridges after } \\
\text { veneering and mechanical fatigue } \\
\text { testing. }\end{array}$ & $\begin{array}{l}\text { Dent Mater. } 2005 \\
\text { May;21(5):476-82. }\end{array}$ & $\begin{array}{l}\text { No initial fracture } \\
\text { load. }\end{array}$ \\
\hline 47 & $\begin{array}{l}\text { Tsalouchou E, } \\
\text { Cattell MJ, } \\
\text { Knowles JC, } \\
\text { Pittayachawan } \\
\text { P, McDonald } \\
\text { A. }{ }^{69}\end{array}$ & $\begin{array}{l}\text { Fatigue and fracture properties of } \\
\text { yttria partially stabilized zirconia } \\
\text { crown systems. }\end{array}$ & $\begin{array}{l}\text { Dent Mater } \\
2008 ; 24: 308-318 .\end{array}$ & $\begin{array}{l}\text { No initial fracture } \\
\text { load. }\end{array}$ \\
\hline & Vult von & Fracture strength of two oxide & J Oral Rehabil & $\begin{array}{l}\text { No initial fracture } \\
\text { load. }\end{array}$ \\
\hline
\end{tabular}




\begin{tabular}{|c|c|c|c|c|}
\hline 48 & $\begin{array}{l}\text { Steyern P, } \\
\text { Ebbesson S, } \\
\text { Holmgren J, } \\
\text { Haag P, Nilner } \\
\mathrm{K}^{70}\end{array}$ & $\begin{array}{l}\text { ceramic crown systems after } \\
\text { cyclic pre-loading and } \\
\text { thermocycling. }\end{array}$ & 2006;33:682-689. & \\
\hline 49 & $\begin{array}{l}\text { Zahran M, El- } \\
\text { Mowafy O, } \\
\text { Tam L, Watson } \\
\text { PA, Finer Y. }\end{array}$ & $\begin{array}{l}\text { Fracture strength and fatigue } \\
\text { resistance of all-ceramic molar } \\
\text { crowns manufactured with } \\
\text { CAD/CAM technology. }\end{array}$ & $\begin{array}{l}\text { J Prosthodont } \\
2008 ; 17: 370-377 .\end{array}$ & $\begin{array}{l}\text { No final fracture } \\
\text { load. }\end{array}$ \\
\hline 50 & $\begin{array}{l}\text { Zhao K, Wei } \\
\text { YR, Pan Y, } \\
\text { Zhang XP, } \\
\text { Swain MV, } \\
\text { Guess PC. }\end{array}$ & $\begin{array}{l}\text { Influence of veneer and cyclic } \\
\text { loading on failure behavior of } \\
\text { lithium disilicate glass-ceramic } \\
\text { molar crowns. }\end{array}$ & $\begin{array}{l}\text { Dent Mater } \\
\text { 2014;30:164-171. }\end{array}$ & $\begin{array}{l}\text { Monolithic } \\
\text { restorations. }\end{array}$ \\
\hline
\end{tabular}

Supplement 1. Articles excluded after full-text screening and data analysis. 